University of Tennessee Law

Legal Scholarship Repository: A Service of the Joel A. Katz Library

UTK Law Faculty Publications

2018

Constitutional Parenthood

Michael J. Higdon

Follow this and additional works at: https://ir.law.utk.edu/utklaw_facpubs

Part of the Law Commons 


\section{University of Tennessee College of Law}

From the SelectedWorks of Michael J Higdon

2018

\section{Constitutional Parenthood}

Michael J Higdon 


\title{
Constitutional Parenthood
}

\author{
Michael J. Higdon*
}

\begin{abstract}
Despite having recognized the constitutional rights of parents almost a hundred years ago, the Supreme Court has not weighed in on the subject of who qualifies as a "parent" under the Fourteenth Amendment in 3o years. In light of the Court's silence, the states have been forced to individually grapple with the issue of constitutional parenthood-a task made exponentially more difficult by the fact that the last 30 years have ushered in an avalanche of change when it comes to the American family. With advances in assisted reproduction, the legalization of same-sex marriage, and the increased frequency of divorce, remarriage and cohabitation, states now regularly encounter claims of parental identity that 30 years ago would have been unimaginable. Nonetheless, the states have persevered, adopting a number of approaches to deal with these increasingly thorny issues. The problem, however, is that the constitutional protections that are afforded parents now vary by state. Moreover, some states have defined "parent" in a way that discriminates against families that do not comport with that state's conception of the "ideal" family. To solve this problem, this Article makes two proposals. First, the Supreme Court must offer more guidance on how states may define constitutional parenthood. Although a definitive definition of the term is both impractical and unrealistic, the Court can and should delineate the outer boundaries of that constitutional standard. Second, taking a cue from some of the tests developed by the states, this Article proposes what exactly those boundaries should be so as to help craft a definition of constitutional parenthood that is more responsive to and protective of the 2 Ist century family.
\end{abstract}

I. INTRODUCTION. 1484

II. PARENTAL Status Under The CONSTITUTION 1491

III. STATE APPROACHES TO "PARENTHOOD" 1502

A. ASSISTED REPRODUCTION................................................. 1503

* Professor of Law, University of Tennessee College of Law. I am grateful to the University of Tennessee College of Law, particularly Dean Melanie Wilson, for providing generous financial support for this project.

1483 
1. Artificial Insemination ........................................... $155^{\mathrm{O}}$

$i$. Sperm Donor as Father........................................... 1504

ii. Husband of Artificially Inseminated Woman as Father........................................................... 15 o6

2. Gestational Surrogacy ............................................ 1508

i. Egg Donor as Mother .......................................... 1509

ii. Gestational Surrogate as Mother.............................1 $15^{10}$

iii. Intended Mother as Mother .....................................1 $15^{11}$

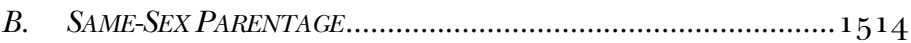

C. THE PSYCHOLOGICAL PARENT ............................................. 1518

IV. Defining Twenty-First Century PARENThoOd .....................1 1524

A. BIOLOGY PLUS INTENT ............................................... 1525

1. The Limited Role of Biology …............................ 1529

2. The Historical Link Between Parental Identity and Intact Families.............................................. $15^{29}$

3. The Importance of Safeguarding Familial

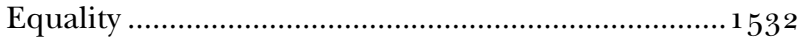

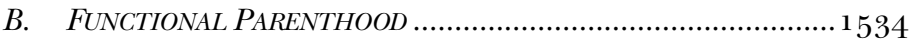

C. PSYCHOLOGICAL PARENTAGE AND State AUtonomy............. 1538

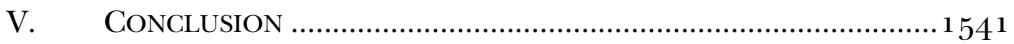

"Constitutions fail when they ignore our nature."

\section{INTRODUCTION}

Problems arise when the Supreme Court interprets constitutional rights in such a way that states are left uncertain as to the exact reach of those rights. Consider, for instance, in 2002, when the Supreme Court ruled that it is a violation of the Eighth Amendment's prohibition against cruel and unusual punishment to execute defendants who are mentally handicapped. ${ }^{2}$ Despite recognizing that "there is serious disagreement" as to "which offenders are in fact" entitled to this protection, the Court nonetheless left "to the State[s] the task of developing appropriate ways to enforce the constitutional restriction upon [their] execution of sentences."3 In other words, the Court charged the states with implementing this ban, including how to define the very term “mentally handicapped." In so doing, the Court's opinion "created a maze of statutory and judicial schemes for the protection of the intellectually

1. Philemon Bliss, Of SOVEREIGNTY 17 (1885).

2. Atkins v. Virginia, 536 U.S. 304, 321 (2002).

3. Id. at 317 (quoting Ford v. Wainwright, 477 U.S. 399, 416-17 (1986)). 
disabled."4 More specifically, by deputizing the individual states, the Court's decision led to a system in which those "[w] ho actually enjoy[] the benefit of those protections varies by state, and the amount of proof defendants must make to garner that protection is similarly varied." 5 Even more troubling was the fact that some states applied the Court's directive so restrictively that individuals with questionable cognitive abilities were nonetheless being sentenced to death. ${ }^{6}$ For that reason, the Court would soon have to issue another opinion on this topic, clarifying that, in determining whether a defendant qualifies as mentally handicapped, states could not simply rely on a bright-line IQ test threshold requirement.7 Three years later, as states continued to experiment with how to define the term, the Court weighed in once again, this time holding that states must use legitimate medical diagnostic tools when determining whether a defendant was mentally handicapped ${ }^{8}$ Thus, within a short period of time, the Supreme Court would issue three separate opinions on how states must define "mental handicap" for purposes of ascertaining a defendant's constitutional rights.

A similar, yet unresolved issue stems from the way states may define "parent." Like the mentally handicapped, the Constitution provides protections to parents-in this instance, under the Fourteenth Amendment.9 In fact, the Supreme Court has gone so far as to characterize the constitutional rights of parents to the care and upbringing of their children as being "perhaps the oldest of the fundamental liberty interests recognized by this Court." ${ }^{\circ}$ But who qualifies as a parent? Despite the fact that the Court first recognized the constitutional rights of parents in the mid-1920s, ${ }^{11}$ the Court, in sharp contrast to the Supreme Court's guidance on the definition of "mental handicap," has not weighed in on the issue of parental identity in over a quarter of a century. ${ }^{12}$ The Court's reticence might be understandable if it had already put forth a satisfactory or even a workable definition of that

4. Ethan A. Wilkinson, Article, Eighth Amendment Protections in Capital Proceedings Against the Intellectually Disabled: Assessing State Methods of Class Protection Through the Lens of Hall v. Florida, $4^{\mathrm{o}}$ L. \& PSYCHOL. REV. 321,342 (2O16).

5. $I d$.

6. See Penny J. White, Treated Differently in Life but Not in Death: The Execution of the Intellectually Disabled After Atkins v. Virginia, 76 TENN. L. REv. 685, 692-710 (2009) (noting the varying state policies regarding execution of the mentally handicapped).

7. See Hall v. Florida, 134 S. Ct. 1986,1990 (2014)

8. See Moore v. Texas, 137 S. Ct. $1039,105^{0}-5^{1}$ (2017).

9. See infra notes $49-53$ and accompanying text.

10. Troxel v. Granville, 530 U.S. 57,65 (2000).

11. Meyer v. Nebraska, 262 U.S. 390 , 400 (1923), is credited as being the first case to recognize the fundamental right of parents. There, when discussing the Liberty Clause of the Fourteenth Amendment, the Court stated that, "[w] ithout doubt, it denotes not merely freedom from bodily restraint but also the right of the individual to [among other things,] establish a home and bring up children." Id. at 399 .

12. See generally Michael H. v. Gerald D., 491 U.S. 110 (1989) (the last case to do so). See infra notes $112-30$ and accompanying text. 
term. When it comes to constitutional "parenthood," however, that simply is not the case. Instead, the Supreme Court has typically deferred to state court determinations of parental identity when adjudicating those individual's constitutional rights. ${ }^{13}$

Of course, for much of our nation's history, the Court would have had little to say on the topic given that parenthood determinations were tied almost exclusively to marriage and, thus, the identity of a child's parents was rarely in dispute. ${ }^{14}$ In essence, the woman who gave birth to the child was the mother, and that woman's husband was the father. ${ }^{15}$ If the mother was not married, then the child was regarded as having no legal parents. ${ }^{16}$ Beginning in the late 196os, however, the law began to recognize that a parent-child relationship could exist outside of marriage. ${ }^{17}$ Consequently, the question of parenthood became more complex, requiring the Court to weigh in. Therefore, in a quintet of cases, all of which were brought by nonmarital fathers, the Supreme Court did just that-suggesting that there are indeed some limits to the state's ability to define legal parenthood. ${ }^{18}$ It is only within the nonmarital, biological father context, however, that the Court has offered any guidance on the broader topic of constitutional parenthood. In fact, the last case in the quintet was in 1989-almost 30 years ago. ${ }^{19}$

The Court's sustained silence is particularly problematic in light of the dramatic changes to the American family during that time. These changes have raised a number of questions that, 30 years ago, would have been unheard of. ${ }^{20}$ These societal changes fall into three broad categories, and each further complicates the issue of parental identity.

First, advances in assisted reproduction have expanded the number of individuals who can play a role in conceiving a single child. ${ }^{21}$ Imagine, for

\footnotetext{
13. See, e.g., Elk Grove Unified Sch. Dist. v. Newdow, 542 U.S. 1, 17-18 (2004) (dismissing action brought by biological father on behalf of son given that the mother, by virtue of a state court order, had sole legal custody); Prince v. Massachusetts, $3_{2} 1$ U.S. $15^{8}$, 171 (1944) (treating aunt, who under state law was the child's legal custodian, as a constitutional parent).

14. See Douglas NeJaime, Marriage Equality and the New Parenthood, 129 HARV. L. REV. 1185 , 1193 (2016) ("Traditionally, marriage defined the scope of state-recognized parenting.").

15. Janet L. Dolgin, Just a Gene: Judicial Assumptions About Parenthood, 4o UCLA L. REV. 637, 644 (1993) ("A child's mother was the woman who bore the child. Biology-including both genetics and the processes of pregnancy and birth-was paramount and decisive." (footnote omitted)); Jennifer S. Hendricks, Essentially a Mother, 13 WM. \& MARY J. WOMEN \& L. 429, 440 (2007) ("[T] raditionally, in the context of marriage, a father's rights derive from his relationship with the mother."); see also infra note 59 and accompanying text.

16. See infra notes $62-63$ and accompanying text.

17. See infra notes $64-68$ and accompanying text.

18. See infra Part II.

19. Michael H. v. Gerald D., 491 U.S. 110,110 (1989).

20. See David D. Meyer, The Constitutionality of "Best Interests" Parentage, 14 WM. \& MARY BILL RTS. J. 857, 857 (2006) ("Judges and legislators around the country are wrestling with the question [of parentage] as never before.").

21. See infra Part III.A.
} 
instance, an infertile couple acquires sperm from a sperm donor, uses that sperm to fertilize an egg provided by an egg donor, and then implants that fertilized egg in a gestational surrogate with the expectation that the surrogate will turn the child over to the commissioning couple after birth. In such a scenario-which is far from uncommon-the resulting child would owe its existence to the coordinated efforts of five individuals. ${ }^{22}$ But who among them would qualify as that child's legal parents?

Second, the legal recognition of same-sex marriage has posed additional complications for parenthood. As the Court recognized in Obergefell v. Hodges, "hundreds of thousands of children are presently being raised by [same-sex] couples." ${ }^{33}$ However, because medical science currently does not permit two people of the same gender to conceive, children of same-sex couples will have-at most - a biological connection with only one adult member of the family. What then is the legal status of the other adult who does not have a biological connection to the child? Is that person a "parent?" Legally, can a child even have two mothers or two fathers? Finally, issues of parenthood have also become more complicated through the rise in both divorce and nonmarital cohabitation. ${ }^{24}$ Specifically, as adult relationships become less formal and more short-term, it is not uncommon for children to have "legal strangers" come into their lives, occupy a parental role, and in the process, develop strong emotional ties with the child-a phenomenon many have come to refer to as "psychological parentage." ${ }_{55}$ Given, however, the lack of a biological or legal connection to the child, can such an individual ever become a "parent?" And, if so, how does such recognition impact the parental rights of the child's biological parents?

These are but a few of the complex questions relating to parental identity that the states have been forced to address. Given the lack of any meaningful guidance from the Supreme Court, the states have had to independently determine how these changes impact constitutional parenthood. After all, the Court has only addressed the subject of parental identity in the context of nonmarital fathers, a factual setting unlike those the state courts are currently

22. See John Lawrence Hill, What Does It Mean to Be a "Parent"? The Claims of Biology as the Basis for Parental Rights, 66 N.Y.U. L. REV. 353, 355 (1991) ("We now live in an era where a child may have as many as five different "parents.'”). Or perhaps more than five. See Jessica R. Hoffman, Essay, You Say Adoption, I Say Objection: Why the Word War Over Embryo Disposition Is More Than Just Semantics, 46 FAM. L.Q. 397, 401 (2012) ("A legal ramification of ART is that there could conceivably be six 'parents' to a given embryo. One embryo could have a sperm donor, egg donor, surrogate carrier, surrogate's husband, and two intended parents.").

23. Obergefell v. Hodges, 135 S. Ct. 2584,2600 (2015).

24. See infra Part III.C.

25. See, e.g., Katharine T. Bartlett, Rethinking Parenthood as an Exclusive Status: The Need for Legal Alternatives When the Premise of the Nuclear Family Has Failed, 7o VA. L. REV. 879, 946 (1984) ("Psychological parents are adults who provide for the physical, emotional, and social needs of the child, needs normally satisfied by the child's nuclear family." (footnote omitted)). 
encountering. ${ }^{26}$ Not surprisingly, then, the states have developed widely disparate standards for defining "parent," meaning an individual may currently qualify as a parent in one state but not another. ${ }^{27}$ Therefore, a person's ability to claim parenthood and its attendant constitutional protections has become dependent upon how tolerant and inclusive that person's state is when it comes to these new forms of parenting.

The Supreme Court has already made clear that "we cannot leave to the States the formulation of the authoritative laws, rules, and remedies designed to protect people from infractions by the States of federally guaranteed rights." ${ }^{28}$ As to the constitutional rights that flow from parenthood, however, that is precisely what is happening. Of course, given that the law of domestic relations has long been viewed as the province of state law, ${ }^{29}$ the fact that states would define "parent" differently is to be expected and, to an extent, entirely appropriate. States, for instance, remain free to define such things as the age of consent, the procedures for adoption, and how property is to be divided at divorce. $3^{\circ}$ However, for those aspects of family law that implicate constitutional protections, the state's ability to regulate is more circumscribed-such regulations must comport with all relevant constitutional safeguards. ${ }^{31}$ Marriage provides a helpful example of this distinction. Marriage is an institution over which the states have historically enjoyed broad legislative authority, including such determinations as the age at which one can wed and whether a formal ceremony is required. At the same time, marriage is also a fundamental right under the Fourteenth Amendment, and as such, state efforts to restrict access to marriage have been repeatedly struck down as unconstitutional. $3^{2}$

26. See infra Part III

27. Meyer, supra note 20, at 880 ("At present, parentage law is growing more incoherent because of ill-considered responses by courts and legislatures to new methods of scientific proof of paternity, breakthroughs in reproductive technology, and changes in family living patterns.").

28. Chapman v. California, 386 U.S. 18, 21 (1967).

29. See, e.g., Sosna v. Iowa, 419 U.S. 393, 404 (describing family law as "an area that has long been regarded as a virtually exclusive province of the States"); Courtney G. Joslin, Federalism and Family Status, 9o IND. L.J. 787,798 (2015) ("[I]t is true that the federal government often defers to or incorporates state family status rules.”).

3o. See Trammel v. United States, 445 U.S. 4o, $5^{\circ}$ (1980) (noting that "the laws of marriage and domestic relations are concerns traditionally reserved to the states").

31. See, e.g., Lehr v. Robertson, 463 U.S. 248, 257 (1983) (“[T]he Federal Constitution supersedes state law and provides even greater protection for certain formal family relationships.”).

32. See generally Obergefell v. Hodges, 135 S. Ct. $25^{84}(2015)$ (striking down prohibition on same-sex marriage); Turner v. Safley, 482 U.S. 78 (1987) (finding that a Missouri statute was unconstitutional because it restricted marriage for inmates); Zablocki v. Redhail, 434 U.S. 374 (1978) (finding that a Wisconsin statute was unconstitutional because it restricted marriage for residents with outstanding child support obligations); Loving v. Virginia, 388 U.S. 1 (1967) (finding that Virginia's statute prohibiting marriage based upon racial classification was unconstitutional). 
Parenthood is very much like marriage in that it is not only a fundamental right, it is also an unenumerated right. 33 Thus, because such "rights provide no inherent mechanism of interpretation," 34 the Court must supply some basis for defining not only the right itself, but also the rightholders if the states are to understand the constitutional boundaries within which they can affirmatively legislate. 35 In Obergefell v. Hodges, the Supreme Court did just that when it spoke to the definition of "marriage," making clear that the states cannot constitutionally exclude same-sex marriages from that term. ${ }^{36}$ But what about "parenthood?" Although the Court has not said much on the issue of parental identity, what it has said reveals that there are indeed constitutional limits on who can be excluded from the definition of parent. It is the position of this Article, however, that more is needed-much more. Specifically, those currently understood limits, when applied to the myriad of familial arrangements existing today, are entirely insufficient to protect 21 stcentury parentage.

Of even greater concern, however, is how the lack of guidance has allowed some states to openly discriminate against forms of parentage the state has deemed contrary to that state's idea of family. 37 As one scholar has aptly noted, the "recognition of the fact of greater family diversity does not translate into accepting or valuing all such diversity." ${ }^{8}$ Indeed, in the wake of Obergefell, a number of states have attempted to offset the rights same-sex couples achieved through marriage equality by simultaneously constricting their ability to qualify as parents to the children of those marriages. 39 Professor Douglas NeJaime predicted as much in 2016 when he warned that "there is certainly cause for concern that, going forward, marriage equality will lead courts and legislatures to limit nonmarital paths to legal parentage for nonbiological parents." $4^{\circ}$ Furthermore, it is not just same-sex marriage that is prompting states to become more restrictive in how they define parenthood. Developments in assisted reproduction and the recognition of

33. See David A.J. Richards, Constitutional Legitimacy and Constitutional Privacy, 61 N.Y.U. L. REV. 80o, 834 (1986) ("The right to marriage is not a textually specified one, so its existence must depend on a conception of unenumerated reserved rights ....”).

34. John F. Basiak, Jr., Inconsistent Levels of Generality in the Characterization of Unenumerated Fundamental Rights, 16 U. FLA. J.L. \& PUB. POL'Y 401, 406 (2005).

35. Anthony Miller, The Case for the Genetic Parent: Stanley, Quilloin, Caban, Lehr, and Michael H. Revisited, 53 LOY. L. REV. 395, 398 (2007) ("The power to determine who can exercise a right is as important as the determination of the right itself.").

36. Obergefell, 135 S. Ct. at 2607 ("The Constitution, however, does not permit the State to bar same-sex couples from marriage on the same terms as accorded to couples of the opposite sex.").

37. Cf. Hendricks, supra note $1_{5}$, at 433 ("[T] he rights of parenthood would erode if states could deny them merely by changing the legal definition of parents.").

38. Linda C. McClain, A Diversity Approach to Parenthood in Family Life and Family Law, in What is Parenthood: Contemporary Debates About The Family 41, 49 (Linda C. McClain \& Daniel Cere eds., 2013).

39. See infra Part III.B.

40. NeJaime, supra note 14 , at 1249 . 
psychological parentage has likewise prompted similar attempts "to preserve the old order" ${ }^{11}$ of conceptualizing the parent-child relationship. As Professor Janet Dolgin describes, "[t]o safeguard treasured forms in the face of changing values and structures, courts have considered, and then sometimes shifted or defined anew, the key symbols through which families are discussed and understood." $4^{2}$

Thus, the aim of this Article is twofold. The first is doctrinal. Quite simply, it is incumbent on the Supreme Court to provide greater insight on the meaning of "parent" as that term has been used to describe and fashion the corresponding constitutional right. Admittedly, parenthood is a complex concept and one that does not lend itself-especially in modern society-to a single definition. Nonetheless, like all constitutional rights, it must necessarily possess some core limits that bind the states. Without additional guidance from the Court, however, even those basic boundaries cannot be sketched, leaving states to define parenthood so disparately that the availability of those constitutional protections varies significantly by state. The second aim of this article is normative; it proposes a new standard for constitutional parenthood that meaningfully protects the expanded class of individuals now claiming parental status, while safeguarding the state's legitimate interests in protecting the well-being of its children. After all, recognizing too many individuals as "parent" to a given child, "will increase the possibility of conflict among the adults that will harm children." 43 As Professor Jeffrey Shulman has argued, " $[\mathrm{t}]$ he best interests of the child are not served by granting rights to more and more parental claimants or by creating new varieties of constitutionally protected parenthood." 44

Although other scholars have noted the lack of any uniform definition of constitutional parenthood, 45 the few that have proposed a solution have done so primarily by focusing on state solutions. $4^{6}$ This Article, although agreeing

41. Dolgin, supra note ${ }_{15}$, at 639 ("The ideology of family has stubbornly resisted change."); see also infra Part III (describing different methods of reproduction that have developed in the modern age, as well as resistance by some states to recognize new forms of parenthood).

42. Dolgin, supra note ${ }^{2} 5$, at 640 .

43. Josh Gupta-Kagan, Non-Exclusive Adoption and Child Welfare, 66 ALA. L. REv. 715, 742 (2015).

44. JefFrey Shulman, The Constitutional Parent: Rights, Responsibilities, And the ENFRANCHISEMENT OF THE CHILD 205 (2014).

45. See, e.g., David D. Meyer, Partners, Care Givers, and the Constitutional Substance of Parenthood,

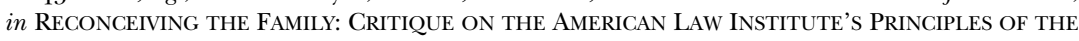
LAW OF FAmily Dissolution 47, 49 (Robin Fretwell Wilson ed., 20o6); Emily Buss, "Parental" Rights, 88 VA. L. REV. 635, 635-36 (2002); Miller, supra note 35, at 398; Douglas NeJaime, The Nature of Parenthood, 126 YALE L.J. 226o, 2264 (2017); Jeffrey A. Parness, Federal Constitutional Childcare Parents, 9o ST. JOHN's L. REV. 965, 971-72 (2016).

46. See, e.g., Buss, supra note 45 , at 636 (advocating a system "that affords the state substantially more authority to assign parental identity where that identity is in dispute"); NeJaime, supra note 45 , at 2269-70 ("State legislatures can restructure parentage law in ways that credit parenthood's social dimensions, and state courts can apply parentage principles to recognize as legal parents those who have committed to the work of parenting."). 
that the states can continue to play a role in some regards, instead argues that parental identity needs to begin with the Supreme Court. That solution is, quite simply, a more contemporary definition of constitutional parenthood, one that will better protect the rights of modern families. Additionally, this Article is the first to propose what exactly that definition should be. Specifically, using state approaches as a guide, this Article advocates for a definition of constitutional parenthood that accounts not only for those who share a biological connection to the child, but also those who were the intended parents of the resulting child, regardless of biology. This Article reaches that conclusion by following an analysis similar to the one the Court took in Obergefell; namely, this Article deconstructs the fathers' rights cases to analyze the "essential attributes" 47 of those decisions—attributes that likewise mandate the inclusion of intentional parentage within the definition of constitutional parenthood. $4^{8}$

This Article proceeds as follows: Part II introduces the fundamental right of parents, focusing primarily on the fathers' rights cases-a series of five cases which mark the only time the Court has delved into the issue of who states must include in their definitions of "parent." Part III then looks at the years that have elapsed since the Court last weighed in on the issue of parental identity, surveying the various approaches the states have taken when applying their state parentage laws to the evolving realities of American parenthood. In Part IV, the Article argues that, after 30 years, the time is ripe for the Court to turn once again to the issue of parental identity, so as to help shape a standard that is not only more uniform but more protective of contemporary family structures. Finally, this Article puts forth a new definition for constitutional parenthood-one that helps better achieve familial equality, yet one that also preserves the states' ability to legislate in such a way as to safeguard the wellbeing of their citizens.

\section{PARENTAl STATUS UNDER THE CONSTITUTION}

In 2000, Justice O'Connor declared, in her plurality opinion in Troxel $v$. Granville, that "the interest of parents in the care, custody, and control of their children-is perhaps the oldest of the fundamental liberty interests recognized by this Court." 49 As the Supreme Court has made clear: "The child

47. Obergefell v. Hodges, 135 S. Ct. 2584,2598 (2015). In Obergefell, the Court concluded that the fundamental right to marry must likewise include the right to same-sex marriage given that "the basic reasons why the right to marry has been long protected . . . demonstrate that the reasons marriage is fundamental under the Constitution apply with equal force to same-sex couples." Id. at 2599 .

48. See infra Part IV.A.

49. Troxel v. Granville, 530 U.S. 57, 65 (2000). Despite O'Connor's characterization, however, the actual history behind the development of this right demonstrates that-unlike other rights traditionally considered "fundamental"-its status is far less certain. Id. at 92 (Scalia, J., dissenting) ("Only three holdings of this Court rest in whole or in part upon a substantive constitutional right of parents to direct the upbringing of their children-two of them from an 
is not the mere creature of the State; those who nurture him and direct his destiny have the right, coupled with the high duty, to recognize and prepare him for additional obligations." $5^{\circ}$ These constitutional protections include the "right to the care, custody and companionship of [the] child as well as the right to make decisions affecting the welfare of the child free from government interference, except in compelling circumstances." $5^{1}$ Thus, beyond simply protecting a parent's decision-making authority, the Fourteenth Amendment also protects the emotional bonds that exist between parent and child, effectively "prevent[ing] the state from seizing newborns and distributing them to parents by some administrative scheme. ${ }_{52}^{2}$ In other words, there is no question that the Constitution protects the rights of parents.

The Constitution does not, however, define "parent." 53 Thus, that definition must come from the Court, which has, in fact, issued five decisions on this topic.54 However, the last of these cases was issued 30 years ago, and, even then, as the remainder of this Part details, the Court's treatment has been episodic, with the result that the Court has never systematically addressed the basic question of how parenthood should be defined for purposes of the Fourteenth Amendment. 55

As an initial point, Supreme Court cases dealing with parental identity, in contrast to parental rights, did not even arise until relatively recently..$^{6}$ That delay is hardly surprising, however, when one considers that, for much of our

era rich in substantive due process holdings that have since been repudiated." (footnote omitted)); see also SHULMAN, supra note 44, at 8 (describing the right as "tenuous" and noting that "no Supreme Court holding supports this claim"- that the right is truly fundamental).

$5^{\text {o. }}$ Pierce v. Soc'y of Sisters, 268 U.S. $5^{10,535}$ (1925).

$5^{1}$. Katheryn D. Katz, Majoritarian Morality and Parental Rights, $5^{2}$ Alb. L. REV. 405, 406 (1988) (footnote omitted); see also Prince v. Massachusetts, 321 U.S. 158, 166 (1944) ("It is cardinal with us that the custody, care and nurture of the child reside first in the parents, whose primary function and freedom include preparation for obligations the state can neither supply nor hinder.").

52. Hendricks, supra note 15 , at 454 .

53. Miller, supra note 35, at 398 ("While the United States Supreme Court has established that the Constitution protects many parental rights, the Court has essentially left unresolved the issue of who qualifies as a parent."); see also Meyer, supra note 20, at 866 (“[W] hile the Constitution clearly protects 'parents' rights,' it does not clearly or necessarily say who a parent is.”).

54. See generally Michael H. v. Gerald D., 491 U.S. 110 (1989); Lehr v. Robertson, 463 U.S. 248 (1983); Caban v. Mohammed, 441 U.S. 380 (1979); Quilloin v. Walcott, 434 U.S. 246 (1978); Stanley v. Illinois, 405 U.S. 645 (1972).

55. The same can be said of many constitutional rights related to family privacy. As David Meyer has argued, "the Court has been content to let strands of doctrine emerge piecemeal. Rights to abortion, contraception, marriage, kinship, and the custody and rearing of children have, for the most part, sprung up independently of one another, only later converging into a loosely recognized constellation of 'family privacy' rights." David D. Meyer, The Paradox of Family Privacy, 53 VAND. L. REV. 527, $5^{28}$ (2000).

5 . See generally Stanley v. Illinois, 405 U.S. 645 (1972) (discussing that Illinois made no presumption of parental identity for unwed fathers). 
nation's history, identifying an individual's parents posed little difficulty. 57 Historically, parenthood flowed from marriage-reductively, the wife was the mother, and her husband was the father. $5^{8}$ Questions of motherhood never arose because, due to the unavailability of in vitro fertilization, the biological mother and the birth mother would have always been the same person.59 On the other hand, the absence of genetic testing meant that one could never be certain of the biological father's identity. Nonetheless, the law solved that problem by simply ignoring biology and instead linking fatherhood to marriage. ${ }^{6 o}$ Thus, as one leading hornbook on the subject described it:

If a married woman gave birth to a child, her husband was held to be the child's father despite any evidence to the contrary. When a husband went abroad for three years and returned to find his wife with a month-old daughter, the law deemed the daughter to be the husband's child because "the privity between a man and his wife cannot be known." 61

For nonmarital children, parenthood was likewise quite easy to determine-the law simply viewed them as having no legal parents. ${ }^{62}$ Considered "filius nullius," or "the child and heir of no one," illegitimate children had no legal relationship to either parent. ${ }^{63}$ As John Dewey explains, "it was not understood to deny the fact of physiological begetting; it was asserting that such [children] did not possess the specific rights which belong to one who was filius, implying wedlock as a legal institution." ${ }_{4}$

Starting in the late 196os, however, the Supreme Court began striking down laws that discriminated against nonmarital children. The first case to do so was Levy v. Louisiana, in which the Court struck down a Louisiana statute that prevented five nonmarital children from bringing an action for the

57. See Meyer, supra note 20, at 859 ("Until quite recently, parentage appeared to be a 'settled category' in the law.").

$5^{8}$. See supra note 15 and accompanying text.

59. It was not until 1978 that the first successful in vitro fertilization procedure occurred. See Kevin Yamamoto \& Shelby A.D. Moore, A Trust Analysis of a Gestational Carrier's Right to Abortion, 7 O FORDHAM L. REV. 93, 97 (2001).

6o. See Michael Grossberg, Governing the Hearth: LaW And the Family in NineteenthCENTURY AMERICA 197 (1985) ("The law used matrimony to separate legal from spurious issue."); Miller, supra note 35 , at 444 ("The law did not traditionally protect the rights of the genetic parent simply because the child's genetic parent could not be determined with certainty.").

61. William M. McGovern, JR. Et Al., Wills, Trusts and Estates InCluding Taxation AND FUTURE INTERESTS 34-35 (1988). Thus, historically, "[n]ature identifies mothers .... $[\mathrm{F}]$ atherhood can only be presumed through a man's relation to the child's mother." Dolgin, supra note 15 , at 644 .

62. Judith Lynn Bick Rice, The Need for Statutes Regulating Artificial Insemination by Donors, 46 OHIO ST. L.J. 1055, 1057 n.20 (1985) ("At common law, an illegitimate child had no legal parents.").

63. See Dorothy E. Roberts, The Genetic Tie, 62 U. CHI. L. REV. 209, 253 \& n.183 (1995) (quoting GROSSBERG, supra note 6o, at 197).

64. John Dewey, The Historic Background of Corporate Legal Personality, 35 YALE L.J. 655,656 ( 1926 ). 
wrongful death of their mother. ${ }^{65}$ Using the Equal Protection Clause, the Court concluded "that it is invidious to discriminate against [nonmarital children] when no action, conduct, or demeanor of theirs is possibly relevant to the harm that was done the mother."66 In a companion case, Glona $v$. American Guarantee $\mathcal{E}$ Liability Insurance Co., the Court held that it was likewise unconstitutional to prevent a biological parent from suing for the wrongful death of a nonmarital child. ${ }^{67}$

In the years immediately following Levy and Glona, the Court continued to invalidate longstanding statutes that discriminated against nonmarital children. ${ }^{68}$ As a consequence, novel issues of paternity began to arise, forcing states to address an issue it had never before really had to consider: Who qualifies as a parent? After all, as illustrated by the Court's holdings in Levy and Glona, if nonmarital children had rights, then so too did nonmarital parents. However, in the parental context, because the law could not look to marriage to determine parentage, new means of identification were now required. For nonmarital mothers, identification was quite simple- “ $[\mathrm{t}]$ he evidence of pregnancy and childbirth was irrefutable." 69 When it came to identifying nonmarital fathers, however, the task was not so simple given that, in contrast to the mother's nine month gestation, "[o]nce a man has contributed genetic material, his biological task is essentially complete."7o Thus, there was nothing as obvious as pregnancy or birth to provide assurances as to the identity of a child's father, nor, at this time, was genetic testing really an option..$^{1}$ Thus, nonmarital fathers presented quite a challenge to the states. Of course, even if a state could identify the biological father, the question remained as to what rights he should hold and whether biology alone was sufficient to entitle him to those rights.

As states experimented with how best to solve these problems, nonmarital fathers began challenging state laws that they felt did not adequately safeguard their parental rights. In Stanley $v$. Illinois, one such challenge quickly made its way to the Supreme Court just four years after Levy and Glona opened

\footnotetext{
65. Levy v. Louisiana, 391 U.S. 68, 71-72 (1968).

66. Id. at 72 (footnote omitted). Notably, the Court reached this result despite the fact that the law at issue "had history and tradition on its side." Id. at 71.

67. Glona v. Am. Guarantee \& Liab. Ins. Co., 391 U.S. 73, $75^{-76}$ (1968).

68. See, e.g., Trimble v. Gordon, 430 U.S. 762 , 776 (1977) (striking down an Illinois statute that barred children from inheriting via intestacy from a nonmarital father); Weber v. Aetna Casualty \& Sur. Co., 406 U.S. 164, 175-76 (1972) (striking down a Louisiana worker's compensation statute that discriminated on the basis of legitimacy).

69. Dolgin, supra note $1_{5}$, at 644 .

7o. Sherry F. Colb, Words that Deny, Devalue, and Punish: Judicial Responses to Fetus-Envy?, 72 B.U. L. REV. 101, 103 (1992).

71. See Thomas H. Murray \& Ross S. White, Genetic Privacy in the United States: Genetic Exceptionalism, GINA, and the Future of Genetic Testing, in GENETIC PRIVACY: AN EVAlUATION OF THE ETHICAL AND LEGAL LANDSCAPE 253, 255 (Terry Sheung-Hung Kaan \& Calvin Wai-Loon Ho eds., 2013) (noting that the use of genetic testing to determine paternity did not emerge until the $1980 \mathrm{os}$ ).
} 
the door to such questions. $7^{2}$ In that case, the Court would issue its first of five opinions dealing with the rights of nonmarital fathers. There, the Supreme Court was confronted with a state law that declared that "the children of unwed fathers become wards of the State upon the death of the mother."73 Pursuant to that law, Peter Stanley had lost his three nonmarital children to the state when their mother died.74 At no time did he receive a hearing to prove that he was a fit parent. Instead, under Illinois law, "the State, on showing that the father was not married to the mother, need not prove unfitness in fact, because it is presumed at law."75 In other words, the state simply did not regard an individual like Stanley to qualify as a parent: “'Parents,' says the State, 'means the father and mother of a legitimate child, or the survivor of them; or the natural mother of an illegitimate child, and includes any adoptive parent,' but the term does not include unwed fathers. " 76 Although the Court had previously appeared quite deferential to states' definitions of parents, 77 for the first time the Court found that a state had crossed an unconstitutional line.

According to the Court, a father's interest "in the companionship, care, custody, and management of his . . . children" is "cognizable and substantial. ${ }^{7} 7^{8}$ More specifically, the Court held that "[t]he private interest here, that of a man in the children he has sired and raised, undeniably warrants deference and, absent a powerful countervailing interest, protection." 79 The Court went on to find that, in terms of his due process argument, the interests put forward by the state were insufficient to overcome the liberty interest of a father in his children. ${ }^{80}$ Additionally, because the state of Illinois did in fact allow hearings to "married parents, divorced parents, and unmarried mothers," the Court likewise ruled "that denying such a hearing to Stanley and those like him while granting it to other Illinois parents is inescapably contrary to the Equal Protection Clause." ${ }^{1}$ Finally, as to the state's freedom to define "parent" narrowly so as to exclude individuals like Stanley, the Court quoted its earlier decision in Glona: "To say that the test of equal protection should be the 'legal' rather than the biological relationship

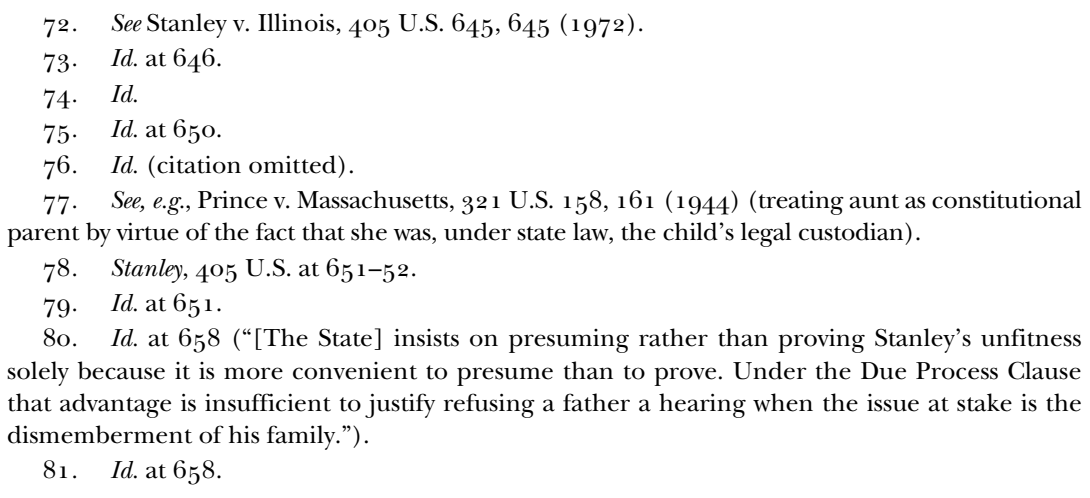


is to avoid the issue. For the Equal Protection Clause necessarily limits the authority of a State to draw such 'legal' lines as it chooses." ${ }^{8_{2}}$ Thus, by holding that the law violated both the Equal Protection and the Due Process clause, the Court made clear that there are indeed limits to how restrictively a state may define the term "parent." ${ }_{3}$

Although Stanley could be read to suggest that constitutional parenthood flowed directly from biological parenthood, the Court would soon make clear that the issue was not quite that simple. In 1978, the Court decided Quilloin $v$. Walcott, a case that involved Leon Quilloin's attempts to veto the adoption of his biological child by the child's stepfather, who had married the mother in 1967 when the child was just three years of age. ${ }^{{ }^{4}}{ }_{4}$ Quilloin and the child's mother were never married. ${ }^{8} 5$ Further, the child had been living with the mother and stepfather since $1969 .{ }^{86}$ Under Georgia law, only the mother's consent was required for the stepparent adoption given that it involved a nonmarital child. ${ }^{87}$ Thus, Quilloin's objections to the adoption were without legal effect, and the stepfather's adoption petition was granted. ${ }^{88}$ Quilloin subsequently brought suit, arguing that the Georgia law violated the Equal Protection Clause in that it "denied him the rights granted to married parents, and presumed unwed fathers to be unfit as a matter of law." ${ }_{9}$

Despite the fact that his status as the child's biological father was not in dispute, the Court in a unanimous opinion ruled that the state could constitutionally treat men like Quilloin differently from other fathers. Specifically, the Court focused on Quilloin's lack of involvement in the child's life, finding that in light of those facts, he was not similarly situated to marital fathers, whose consent would have been required under Georgia law:

$[\mathrm{H}] \mathrm{e}$ has never exercised actual or legal custody over his child, and thus has never shouldered any significant responsibility with respect to the daily supervision, education, protection, or care of the child. . . In contrast, legal custody of children is, of course, a central aspect of the marital relationship, and even a father whose marriage has broken apart will have borne full responsibility for the rearing of

\footnotetext{
82. Id. at $65_{2}$ (quoting Glona v. Am. Guarantee Co., 391 U.S. $73,75^{-76}$ (1968)).

83. See Hendricks, supra note ${ }_{15}$, at 435 ("The core of Stanley is thus the Court's recognition that Stanley was, constitutionally, a parent, whose claim to his children could be overcome only by a compelling state interest, such as his unfitness."); Meyer, supra note 20, at 871 ("Implicit in this holding, of course, was a judgment that unwed fathers such as Peter Stanley are constitutionally entitled to state recognition as parents.").

84. Quilloin v. Walcott, 434 U.S. 246,247 (1978).

85. $I d$.

86. Id. at 247 n.1. As the Court explained, "[t] he child lived with his maternal grandmother for the initial period of the marriage." Id.

87. Id. at $248 \mathrm{n} \cdot 3$ ("If the child be illegitimate, the consent of the mother alone shall suffice.").

88. Id. at 247 .

89. Id. at $25^{\circ}$
} 
his children during the period of the marriage. Under any standard of review, the State was not foreclosed from recognizing this difference in the extent of commitment to the welfare of the child. $9^{\circ}$

The Court pointed out that, although the Due Process Clause "would be offended ' $[\mathrm{i}] \mathrm{f}$ a State were to attempt to force the breakup of a natural family, over the objections of the parents and their children," "91 the facts of Quilloin's case failed to offer such a scenario: "Nor is this a case in which the proposed adoption would place the child with a new set of parents with whom the child had never before lived. Rather, the result of the adoption in this case is to give full recognition to a family unit already in existence." ${ }^{2}$ The Court did little to distinguish the case from Stanley, merely noting that the previous case "left unresolved the degree of protection a State must afford to the rights of an unwed father in a situation, such as that presented here, in which the countervailing interests are more substantial."93

Just one year later, in Caban v. Mohammed, the Court issued its third fathers' rights opinion, ruling that a New York adoption statute, which required the consent of nonmarital mothers but not nonmarital fathers, was unconstitutional as applied to the facts of that case.94 Unlike the nonmarital father in Quilloin, Mr. Caban had "manifested a significant paternal interest in the child[ren]" by both living with and supporting them.95 Although the Court recognized the state's interest in promoting the adoption and wellbeing of nonmarital children, it was nonetheless troubled by the degree to which the law in question discriminated on the basis of gender-a "claim [that] was not properly presented"96 in Quilloin:

The facts of this case illustrate the harshness of classifying unwed fathers as being invariably less qualified and entitled than mothers to exercise a concerned judgment as to the fate of their children. [The New York law] both excludes some loving fathers from full participation in the decision whether their children will be adopted and, at the same time, enables some alienated mothers arbitrarily to cut off the paternal rights of fathers. We conclude that this

\footnotetext{
9o. Id. at $25^{6}$. For similar reasons, the Court found no violation of the Due Process Clause, noting that "this is not a case in which the unwed father at any time had, or sought, actual or legal custody of his child." Id. at 255 .

91. Id. (quoting Smith v. Org. of Foster Families, 431 U.S. 816, 862-63 (1977) (Stewart, J., concurring)).

92. $\quad I d$.

93. Id. at 248 .

94. Caban v. Mohammed, 441 U.S. $380,3^{82}$ (1979)

95. Id. at 394 .

96. Id. at 389 n.7. As the Court explained in Quilloin, "[i]n the last paragraph of his brief, appellant raises the claim that the statutes make gender-based distinctions that violate the Equal Protection Clause. Since this claim was not presented in appellant's jurisdictional statement, we do not consider it." Quilloin, 434 U.S. at 253 n.13.
} 
undifferentiated distinction between unwed mothers and unwed fathers, applicable in all circumstances where adoption of a child of theirs is at issue, does not bear a substantial relationship to the State's asserted interests. 97

Distinguishing its holding in Caban from Quilloin, the Court pointed out that, in Quilloin, "we emphasized the importance of the appellant's failure to act as a father toward his children." 98 Thus, as Professor Janet Dolgin describes it, "Caban suggests that a biological father's paternal behavior will determine the degree of protection the Constitution provides in safeguarding his relationship with his biological child."99

With the Supreme Court now having decided two cases in favor of nonmarital, biological fathers and one against, the stage was set for the Court to synthesize those opinions into one coherent standard-one that would better answer the question of how exactly a nonmarital father acquires constitutional rights to his biological children. The facts of Lehr v. Robertson would provide a perfect opportunity to do just that, and indeed the Court's decision would prove to be a landmark case on the issue of parental identity. ${ }^{100}$ Like the petitioner in Quilloin, Jonathan Lehr was a nonmarital father who had played little role in the life of his child, Jessica. ${ }^{101}$ When Jessica was just eight months old, her mother married another man, Richard Robertson. ${ }^{102}$ When Jessica was two years old, "the Robertsons filed an adoption petition" with the county court. ${ }^{103}$ Under New York law, Lehr was not entitled to notice of the petition. ${ }^{104}$ After Robertson's adoption petition was granted, Lehr filed "a petition to vacate the order of adoption on the

\footnotetext{
97. Caban, 441 U.S. at 394 .

98. Id. at $389 \mathrm{n} .7$.

99. Dolgin, supra note $1_{5}$, at 657 . Dolgin goes on to note, however, that "the language of the opinion focuses on the fact that Caban 'lived together as a natural family' with Maria Mohammed and their children rather than on the character of the relationship that Caban affected with his children." Id.

10o. Lehr v. Robertson, 463 U.S. 248, 248-49 (1983).

101. Id. at $25^{2}$ ("He did not live with appellee or Jessica after Jessica's birth, he has never provided them with any financial support, and he has never offered to marry appellee.").

102. Id. at $25^{\circ}$

103. Id.

104. The law did require that notice be provided to those nonmarital fathers who had registered with the putative father registry:
}

[T] hose who have been identified as the father on the child's birth certificate, those who live openly with the child and the child's mother and who hold themselves out to be the father, those who have been identified as the father by the mother in a sworn written statement, and those who were married to the child's mother before the child was six months old.

$I d$. at $25^{1}$. Lehr, however, did not fall into any of those categories. $I d$. at $25^{1-} 5^{2}$. 
ground that it was obtained by fraud and in violation of his constitutional rights." $10_{5}$

The Court began its analysis by noting that, when it comes to family law, state law definitions typically govern and are "generally specified in statutory enactments that vary from State to State." ${ }^{106}$ The Court, however, was quick to note "that the Federal Constitution supersedes state law and provides even greater protection for certain formal family relationships." ${ }_{107}$ With that understanding, the Court turned to the merits of Lehr's case, taking that opportunity to revisit the previous fathers' rights cases and clarify when exactly a nonmarital father is entitled to constitutional protection.

As an initial point, the Court made clear that biological parentage is not dispositive, ruling that "the mere existence of a biological link does not merit equivalent constitutional protection." ${ }_{108}$ Instead, the Court put forth what is commonly referred to today as the "biology plus" doctrine. ${ }^{109}$ According to the Court, " $[w]$ hen an unwed father demonstrates a full commitment to the responsibilities of parenthood by 'com[ing] forward to participate in the rearing of his child,' his interest in personal contact with his child acquires substantial protection under the Due Process Clause." ${ }_{10}$ In other words, biological parenthood provides a nonmarital father with an incipient right, one that will not fully develop until he takes sufficient steps to foster a parental relationship with the child. Accordingly, the Court upheld the New York law given that it "ha[d] adequately protected his opportunity to form such a relationship." "In the Court's view, the fact that Lehr never seized that opportunity was nobody's fault but his own. ${ }^{112}$

Whatever clarity Lehr provided, however, was short-lived. Six years later, the Court would issue its final fathers' right case, Michael H. v. Gerald D.-a case that continues to call into question the precise reach of the biology plus doctrine. ${ }^{113}$ In that case, Justice Scalia would begin his plurality opinion by 
declaring: "The facts of this case are, we must hope, extraordinary." $11_{4}$ The facts to which Scalia was referring involved the story of four people: The biological mother, Carole; the biological father, Michael; their biological child, Victoria; and the mother's husband, Gerald, to whom Carole was married and had been married throughout the events that gave rise to this litigation. ${ }^{15}$ Carole had an extramarital affair with Michael, resulting in the birth of Victoria. ${ }^{116}$ Despite the fact that Carole was married to Gerald, Michael played an active role in Victoria's life. The child referred to Michael as "Daddy," and he not only spent time with her, but also supported her financially. ${ }^{117}$ Genetic testing proved that Michael was indeed Victoria's father. Gerald, however, was listed as the father on Victoria's birth certificate. ${ }^{118}$ Eventually Gerald and Carole reconciled, and ended Michael's visitation with Victoria.

In response, Michael filed an action in California to establish his paternity and to gain formal visitation. ${ }^{119}$ California's marital presumption, however, provided that "the [child] of a wife cohabiting with her husband, who is not impotent or sterile, is conclusively presumed to be a child of the marriage." ${ }^{120}$ Although one could rebut the presumption with genetic testing, such an action could only be brought within the first two years of the child's life and, even then, only by the husband or the wife. ${ }^{121}$ Accordingly, an individual like Michael, who was a stranger to the marriage, had no right to challenge the paternity of a marital child. Thus, under California law, "[a]11 parental rights, including visitation, were automatically denied by denying Michael status as the father."122

Michael filed an appeal, part of which argued that the California law unconstitutionally infringed upon his substantive due process rightsspecifically, his "constitutionally protected liberty interest in his relationship with Victoria." ${ }^{23}$ Under Lehr, his argument would appear to have some merit. After all, Michael was not only the biological parent of Victoria, but he had also come forward and affirmatively acted as a parent for a significant portion

\footnotetext{
114. Id. at 113

115 . Id. at $113^{-14}$.

$116 . \quad I d$.

117. Id. at 143-44 (Brennan, J., dissenting).

118. Id. at 113 (plurality opinion).

119. Id. at 114 .

120. Id. at 115 (quoting CAL. EvID. CODE $\$ 621$ (a) (West Supp. 1989)).

121. Id. at 115 ("The presumption may be rebutted by blood tests, but only if a motion for such tests is made, within two years from the date of the child's birth, either by the husband or, if the natural father has filed an affidavit acknowledging paternity, by the wife." (citing CAL. EVID. CODE $§ 621(\mathrm{c})-(\mathrm{d})))$.

122. Id. at 119 .

123. Id. at 121 .
} 
of her early life. ${ }^{124}$ The plurality, however, put forth an exception: "Where, however, the child is born into an extant marital family, the natural father's unique opportunity conflicts with the similarly unique opportunity of the husband of the marriage; and it is not unconstitutional for the State to give categorical preference to the latter." ${ }^{25}$ To justify its departure from Lehr, the plurality noted that history and tradition-those areas to which the Court typically looks to for identifying fundamental rights ${ }^{126}$ — was entirely insufficient to elevate Michael's claimed liberty interest to that level:

What counts is whether the States in fact award substantive parental rights to the natural father of a child conceived within, and born into, an extant marital union that wishes to embrace the child. We are not aware of a single case, old or new, that has done so. This is not the stuff of which fundamental rights qualifying as liberty interests are made. ${ }^{127}$

Thus, the Court affirmed the decision of the California court, leaving Michael a legal stranger to the biological child he had previously parented.

Justice Stevens concurred in the plurality's decision but nonetheless wrote separately to make clear that he "would not foreclose the possibility that a constitutionally protected relationship between a natural father and his child might exist in a case like this." ${ }^{28}$ In fact, Stevens noted that he only joined Justice Scalia's opinion because Stevens believed the California law in question gave Michael the opportunity to obtain visitation rights to Victoria. ${ }^{129}$ In light of Steven's concurrence, at least one scholar believes that Michael H. was, essentially, an endorsement of the biology plus doctrine. Specifically, as Professor Anthony Miller explains: "[I]t is apparent that a majority of the Court in Michael H.-Justices Brennan, Blackmun, Marshall, White, the four dissenters, along with Justice Stevens-favored constitutional protection for the genetic participatory parent."130 Nonetheless, other scholars have attempted to synthesize the more restrictive plurality opinion in Michael $H$.

124. Id. at 143-44 (Brennan, J., dissenting) ("The evidence is undisputed that Michael, Victoria, and Carole did live together as a family; that is, they shared the same household, Victoria called Michael 'Daddy,' Michael contributed to Victoria's support, and he is eager to continue his relationship with her.").

125. Id. at 129 (plurality opinion)

126. See Washington v. Glucksberg, 521 U.S. 702, 720-21 (1997) ("[W]e have regularly observed that the Due Process Clause specially protects those fundamental rights and liberties which are, objectively, 'deeply rooted in this Nation's history and tradition." (quoting Moore v. City of East Cleveland, 431 U.S. 494, $5^{\circ 3}$ (1977))).

127. Michael H., 491 U.S. at 127.

128. Id. at 133 (Stevens, J., concurring).

129. Id. ("Indeed, I am willing to assume for the purpose of deciding this case that Michael's relationship with Victoria is strong enough to give him a constitutional right to try to convince a trial judge that Victoria's best interest would be served by granting him visitation rights. I am satisfied, however, that the California statute, as applied in this case, gave him that opportunity.").

13o. Miller, supra note 35 , at 443 . 
with the Court's previous fathers' rights cases-something Justice Scalia's opinion never attempted to do. ${ }^{13^{1}}$ They have theorized that in order to harmonize the five decisions, the test would look something like this: "[F]atherhood is a function of the confluence of three factors: the man's biological relationship with the child, his legal or social relationship with the child's mother, and the extent of his social and psychological commitment to the child." ${ }^{12}$

Whatever its precise meaning, Michael H. not only marked the final case in the fathers' rights cases, it also marked the last time the Court would weigh in on who qualifies as a parent under the Fourteenth Amendment. Thus, since 1989, the Court has provided no further guidance on this very important question-a question that, as Part III details, has become increasingly complicated. Additionally, the fathers' rights cases, although touching on the subject of parental identity, are not sufficiently analogous to contemporary parenthood issues to provide much assistance in adjudicating such claims. Thus, faced with rapidly evolving family structures and with little assistance from the Supreme Court, the states have been forced to take the lead in discerning how to define "parenthood."

\section{StATE APPROACHES TO "PARENTHOOD"}

Since the Supreme Court last spoke on the issue of constitutional parenthood, the states have had to confront a number of societal shifts, all of which have further complicated determinations of parental identity. ${ }^{133}$ These societal changes include advances in assisted reproduction technology, the legalization of same-sex marriage, and the increasingly informal and transitory nature of adult relationships-all of which contribute to what

131. Id. at $43^{8}$ ("Justice Scalia did not explain why he chose to interpret these four cases in the restrictive scope of the 'unitary family,' nor why he chose to ignore the statements in these cases regarding parental participation in the child's life. In support of his narrow view, Justice Scalia quoted from neither Stanley, Quilloin, Caban, nor Lehr. ...”).

132. Hill, supra note 22, at 381 (footnotes omitted); see also David W. Meyer, Family Diversity and the Rights of Parenthood, in WHAT IS PARENTHOOD: CONTEMPORARY DEBATES AbOUT THE FAMILY, supra note 38 , at $124,130-31$ ("The unwed father cases make clear that biology is relevant, as is past caregiving, diligence, and the nature of the mother's relationships with the biological father and, if she is married, her husband. However, no single criterion controls the constitutional definition of parenthood." (footnote omitted)).

133. Mary Ann Glendon, Foreword to RECONCEIVING THE FAMILY: CRITIQUE ON THE AMERICAN LAW INSTITUTE's PRINCIPLES OF THE LAW OF FAMILY DiSSOLUTION, supra note 45, at xiii, xiii ("The late twentieth century was a time of unprecedented changes in family behavior, family law, and ideas about marriage and family life.”); Kerry Abrams \& R. Kent Piacenti, Immigration's Family Values, 100 VA. L. REV. 629, 690 (2014) ("As marriage lost its grip on family law in the twentieth century, and as blood and DNA testing began to make genetic parenthood easier to demonstrate, the importance of marital, genetic, functional, and intentional parenthood shifted in family law, providing broadened recognition of new types of parentage.”); Michael S. DePrince, Note, SameSex Marriage and Disestablishing Parentage: Reconceptualizing Legal Parenthood Through Surrogacy, 100 MINN. L. REV. 797, 806 (2015). ("[A] new understanding of legal parentage has evolved alongside this starkly changing family landscape.”). 
Justice Stevens has described as " $[\mathrm{t}]$ he almost infinite variety of family relationships that pervade our ever-changing society." 134 As state courts have ventured into these new areas, they have developed a number of approaches to help define 2 st-century parenthood. This Part surveys a number of those approaches in an attempt to do two things. First, by noting the degree to which the states are taking disparate approaches to defining parenthood, this Part underscores the need for more guidance on this issue from the Supreme Court. Second, assuming that the Court accepts that invitation, a survey of state innovations in this area will better inform the Court as it considers how best to approach a more contemporary definition of parental identity.

\section{A. ASSISTED REPRODUCTION}

In 2007, a Maryland state court declared: "What had not been fathomed exists today." ${ }^{355}$ With advances in reproductive technology ("ART"), individuals desiring biological children have a number of options to assist in that endeavor. As Anthony Miller explains, "[c]hildren can be conceived in the time honored way of sexual intercourse, through the relatively old technology of artificial insemination, the relatively new technology of in vitro fertilization, and perhaps eventually through the cutting edge technology of cloning." ${ }^{136}$ Each of these options, however, bring with them questions of parenthood. After all, the more people who contribute to the conception of a child, the greater the difficulty in assigning parental identity. The two primary areas of ART which have posed the most difficulties in this regard are artificial insemination, which raises questions about legal fatherhood, and gestational surrogacy, which raises the previously unheard of question of legal motherhood.

\section{Artificial Insemination}

Artificial insemination raises the question of the identity of the legal father. Artificial insemination is a process through which a child is conceived not through sexual intercourse, but through the injection of sperm into the intended mother's cervix. ${ }^{137}$ The man who donates the sperm would, of course, be the biological father of the resulting child, but the question remains as to who-if anyone-is the child's legal father. As detailed below, the states typically bestow that status on the man who is married to the

\footnotetext{
134. Troxel v. Granville, 530 U.S. 57, 90 (2000) (Stevens, J., dissenting); see also Adoptions of B.L.V.B. \& E.L.V.B., 628 A.2d 1271 , 1276 (Vt. 1993) ("It is the advancement of reproductive technologies and society's recognition of alternative lifestyles that have produced families in which a biological, and therefore a legal, connection is no longer the sole organizing principle.").

135. In re Roberto d.B., 923 A.2d 115,122 (Md. 2007).

136. Miller, supra note 35 , at $45^{1}$.

137. Browne C. Lewis, Dead Men Reproducing: Responding to the Existence of Afterdeath Children, 16 GEO. MASON L. REV. 403, 410 (2009).
} 
artificially inseminated woman..$^{138}$ If the woman is unmarried, then the child is treated as having no legal father-one of the few times the law regards a child as having being born with only one legal parent. ${ }^{139}$ Complications arise, however, because there are some circumstances in which a sperm donor can be declared the legal father. Surveying these varying approaches is instructive of how the law has come to view fatherhood and provides a potential rubric for how the Supreme Court can approach the more salient question of who is a parent.

\section{i. Sperm Donor as Father}

If states were to equate biological and legal parenthood, determining the legal father of a child conceived via artificial insemination would be simpleit would be the sperm donor. That is not, however, the approach the states generally take. Consider, for instance, the relevant California statute, which is prototypical of most states: "The donor of semen provided to a licensed physician and surgeon or to a licensed sperm bank for use in assisted reproduction by a woman other than the donor's spouse is treated in law as if he were not the natural parent of a child thereby conceived ..." ${ }^{40}$ Thus, sperm donors are typically denied all parental rights and obligations. ${ }^{14}$ Doing so serves two important objectives. First, it encourages men to donate sperm without fear that they will be required to support the resulting child. ${ }^{12}$

138. See infra Part III.A.1.i.

139. Ralph C. Brashier, Inheritance and Succession, Sociology of, in ENCYCLOPEDIA OF LAW \& Society: American AND Global Perspectives 759, 762 (David S. Clark ed., 2007) (“[T]he woman is the sole legal parent of the child."); Anne Reichman Schiff, Frustrated Intentions and Binding Biology: Seeking AID in the Law, 44 DUKE L.J. 524, 536 (1994) ("Some UPA-based statutes sever the legal relationship between the donor and the child not only when the woman is married, but also when she is single. In these jurisdictions, a child born through AID has no legal father." (footnote omitted)).

140. CAL. FAM. CODE $\$ 7613$ (b) (1) (West 2017) (emphasis added). See generally Christina M. Eastman, Comment, Statutory Regulation of Legal Parentage in Cases of Artificial Insemination by Donor: A New Frontier of Gender Discrimination, 41 MCGEORGE L. REV. 371 (2010) (surveying the various state laws on artificial insemination).

141. See OKLA. Stat. Ann. tit. 10, \$555 (2011) ("An oocyte donor shall have no right, obligation or interest with respect to a child born as a result of a heterologous oocyte donation from such donor. A child born as a result of a heterologous oocyte donation shall have no right, obligation or interest with respect to the person who donated the oocyte which resulted in the birth of the child."); WIS. STAT. $\$ 891.40(2)$ (West 2016) ("The donor of semen provided to a licensed physician for use in artificial insemination of a woman other than the donor's wife is not the natural father of a child conceived, bears no liability for the support of the child and has no parental rights with regard to the child.").

142. See Ex rel. R.C., 775 P.2d 27, 32 (Colo. 1989) (en banc) (noting that such laws "provide[] "men with a statutory vehicle for donating semen to married and unmarried women alike without fear of liability for child support'” (quoting Jhordan C. v. Mary K., 224 Cal. Rptr. 530, 534 (Ct. App. 1986))). 
Second, those who conceive using sperm from a third-party donor can do so without worrying that the donor could make future claims on the child. ${ }^{143}$

Nonetheless, states permit parties to deviate from this general approach and instead grant the sperm donor parental rights and responsibilities. To do so, however, all involved must affirmatively consent to this arrangement. New Jersey law, for example, provides: "Unless the donor of semen and the woman have entered into a written contract to the contrary, the donor ... shall have no rights or duties stemming from the conception of a child." ${ }_{44}$ Other states, even in the absence of a statutory exception, have extended parental rights to sperm donors when the parties' conduct evinces an intent that the donor serve as the child's father. For example, in the Colorado case of Ex rel. R.C., the mother, E.C., asked her friend, J.R., to serve as her sperm donor. ${ }^{145} \mathrm{He}$ agreed, and E.C. (who was unmarried) successfully used his sperm to give birth to a child. ${ }^{1}{ }^{6}$ Following the birth, the mother eventually refused to allow the donor to see the child, prompting him to bring a paternity action. ${ }^{147}$ In his action, the donor claimed that he and the mother had orally agreed that if he provided the sperm then, in exchange, he "would be treated as the father of any child conceived by the artificial insemination." ${ }^{4}{ }^{8}$ Despite a Colorado statute which stated that " $[\mathrm{t}]$ he donor of semen provided to a licensed physician for use in artificial insemination of a woman other than the donor's wife is treated in law as if he were not the natural father of a child thereby conceived," 149 the Supreme Court of Colorado refused to apply it in this situation. ${ }^{15^{\circ}}$ In so ruling, that court first noted that the parental rights of a semen donor are "least clearly understood when the semen donor is known and the recipient is unmarried." ${ }^{1}{ }^{1}$ The court then held that the statute was inapplicable when the man who donated sperm to an unmarried woman did so with the understanding that he would be the father of the resulting child. ${ }^{152}$ The court also noted that the parties' intent is "a relevant consideration in

143. See Browne Lewis, Two Fathers, One Dad: Allocating the Paternal Obligations Between the Men Involved in the Artificial Insemination Process, 13 LEWIS \& CLARK L. REV. 949, 975 (2009); see also Ex rel. R.C., 775 P.2d at 33 ("[W]omen are not likely to use donated semen from an anonymous source if they can later be forced to defend a custody suit and possibly share parental rights and duties with a stranger.").

144. N.J. STAT. ANN. \$ 9:17-44(b) (West 2013).

145. Ex rel. R.C., 775 P.2d at 28. E.C. claimed, however, that it was J.R.'s idea to donate sperm. Id. at $28 \mathrm{n} .1$.

146. Id. at 28 .

147. Id. ("J.R. claims that E.C. said that she would not let him see R.C. again unless he signed a release of his parental rights. He refused to sign the release.").

148. Id.

149. Id. at 30 (quoting COLO. REV. STAT. § 19-4-106(2) (Supp. 1988)).

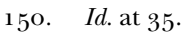

$15^{1 .} \quad I d$. at $33-34$.

152. Id. at 35 ("[T] he General Assembly neither considered nor intended to affect the rights of known donors who gave their semen to unmarried women for use in artificial insemination with the agreement that the donor would be the father of any child so conceived."). 
determining whether the known donor's parental rights were extinguished." ${ }^{153}$ Other states have taken a similar approach, thus permitting sperm donors to essentially contract for parental rights. ${ }^{154}$

Thus, as the law relates to the parentage of sperm donors, biology plays little to no role in their ability to assume parental rights. Instead, it is the intent of the parties that is dispositive. In other words, the fact that the sperm donor is the biological father to the resulting child is irrelevant unless the two biological parents agreed that the donor's contribution would extend beyond donating biological material to actually parenting the resulting child. Of course, these rules apply to situations involving the artificial insemination of unmarried women. As discussed in the next section, when the woman is married, the calculus is quite different.

\section{ii. $\quad$ Husband of Artificially Inseminated Woman as Father}

In a significant number of jurisdictions, if a married woman is artificially inseminated with the sperm of a third party, her husband is considered the child's legal father despite the fact that the child is the biological child of another man. ${ }^{55}$ However, the husband is afforded that status only if he consents to the insemination. ${ }^{15^{6}}$ For example, a Tennessee statute that deals with artificial insemination states that "[a] child born to a married woman as a result of artificial insemination, with consent of the married woman's husband, is deemed to be the legitimate child of the husband and wife." ${ }_{157}$ In terms of what form his consent must take, however, states have adopted different approaches. A few states require that the husband's consent be in writing. ${ }^{15^{8}}$ Most states, however, wishing to avoid situations in which a child is

\footnotetext{
153. Id. at 34 .

154. See, e.g., DEL. CODE ANN. tit. 13, § 8-703 (West 2006) ("A man who provides sperm for, or consents to, assisted reproduction by a woman . . . with intent to be the parent of her child, is a parent of the resulting child.”); McIntyre v. Crouch, 780 P.2d 239, 244 (Or. Ct. App. 1989) (holding that denying sperm donor parental rights would "violate the Due Process Clause of the Fourteenth Amendment if he can establish that he and respondent agreed that he should have the rights and responsibilities of fatherhood and in reliance thereon he donated his semen").

155. See Lewis, supra note 143 , at 960-63.

156. Id.

157. TENN. CODE ANN. \$ 68-3-3o6 (West 2016); see also In re Marriage of Witbeck-Wildhagen, 667 N.E.2d 122, 126 (Ill. App. Ct. 1996) (holding that, because respondent-the husband of petitioner-did not provide "his consent to petitioner or any support to her choice to undergo artificial insemination . . . it would be inconsistent with public policy to force upon respondent parental obligations which he declined to undertake").

158. Consider, for instance, the Minnesota statute, which provides that "the husband is treated in law as if he were the biological father of a child thereby conceived [via artificial insemination]," but, "[t]he husband's consent must be in writing and signed by him and his wife." Minn. STAT. ANN. $\$ 257.56$ (2012); see also Lewis, supra note 143, at 961 n.66 (listing other state statutes that explicitly require written consent).
} 
born with only one legal parent, require very little to satisfy the consent requirement. ${ }^{159}$

Some states presume consent of the husband. For example, in Maryland, "[a] child conceived by artificial insemination of a married woman with the consent of her husband is the legitimate child of both of them for all purposes. Consent of the husband is presumed."16o The husband may have, however, a limited window of time in which he may avoid parental obligations by offering proof that he never in fact consented. ${ }^{161}$ In states without any such presumption, the courts are nonetheless quite liberal in extrapolating consent from the surrounding circumstances. For instance, some states have held that a husband's consent to artificial insemination "may be express, or it may be implied from conduct which evidences knowledge of the procedure and failure to object." ${ }^{162}$ Texas, for example, requires that the husband's consent be in writing, but also provides that the "[f] ailure by the husband to sign a consent ... before or after the birth of the child does not preclude a finding that the husband is the father of a child born to his wife if the wife and husband openly treated the child as their own." ${ }^{163}$

Even in states without statutes directing courts to consider the parties' conduct, courts tend to do so when disputes arise concerning a husband's consent to the artificial insemination of his wife. For example, in the New Mexico case of Lane v. Lane, the husband and wife married in 1984; however, prior to the marriage, the husband underwent a vasectomy. ${ }^{164}$ Thus, the wife elected to conceive using artificial insemination. ${ }^{165}$ Although the husband participated in the process, ${ }^{166}$ he never formally consented in writing. Nonetheless, the husband played an active role in the child's rearing, treating

159. Richard F. Storrow, Parenthood by Pure Intention: Assisted Reproduction and the Functional Approach to Parentage, 53 Hastings L.J. 597, 623-24 (2002) ("Public policy favoring legitimacy and support for children creates a strong presumption that a husband consented to his wife's insemination.").

16o. MD. CODE ANN., Est. \& Trusts § 1-2o6(b) (West 2014); see also ARK. CODE ANN. § 28-9-209(c) (West 2015) ("Any child conceived following artificial insemination of a married woman with the consent of her husband shall be treated as their child for all purposes of intestate succession. Consent of the husband is presumed unless the contrary is shown by clear and convincing evidence.").

161. For example, Delaware law provides that "the husband of a wife who gives birth to a child by means of assisted reproduction" is not liable for child support if "(1) Within [two] years after learning of the birth of the child he commences a proceeding to adjudicate his paternity; and (2) [t] he court finds that he did not consent to the assisted reproduction, before or after birth of the child." DEL. CODE ANN. tit. 13, § 8-705(a) (West 2006). Other states follow a similar approach. See UTAH CODE ANN. § 78B-15-705 (1) (2015); WYO. STAT. ANN. § 14-2-905 (a) (2015).

162. In re Baby Doe, 353 S.E.2d 877, 879 (S.C. 1987) (citing R.S. v. R.S., 670 P.2d 923 (Kan. Ct. App. 1983)).

163. TEX. FAM. CODE ANN. \$ 160.704(a) (2014).

164. Lane v. Lane, 912 P.2d 29o, 292 (N.M. Ct. App. 1996).

165. Id.

166. Id. ("Husband participated in the process, driving Wife for some medical visits, attending birthing classes, and being present in the delivery room ....”). 
the resulting daughter, Colleen, in all respects as his own child. ${ }^{167}$ The couple eventually filed for divorce, and the wife sought sole custody of the child on the grounds that the husband was not the child's father given that he never gave written consent to the insemination as required by state law. ${ }^{168}$ The court rejected her argument, noting at the outset "that even though a statute constitutes a command to the courts regarding what law to apply, the command must be read with intelligence." ${ }^{69}$ Furthermore, in looking at the statute, the court observed that " $[\mathrm{t}]$ he statute does not require any particular form of words for the consent." $17^{\circ}$ With that in mind, the court held that the husband had substantially complied with the statute given the degree to which the parties had publicly held the child out as being the husband's daughter: " $[\mathrm{M}]$ ore than two and one-half years after the birth of Colleen, and even after the marriage had failed, both Husband and Wife were acknowledging Husband's status as Colleen's natural father." ${ }^{171}$

Under the law of artificial insemination, then, a sperm donor can become a legal father by virtue of his biological connection, but only if he and the mother agreed in advance that he be afforded parental rights. In contrast, a man who is married to the inseminated woman can become a legal father despite the fact that he shares no biological relationship with the child so long as he consented to the insemination, which can be shown through his intent (i.e., express consent) or his conduct (i.e., implied consent). Thus, as the law of artificial insemination demonstrates, the path to parenthood has very much become situational, with different rules arising based on the particular relationship of the parties as well as the factual context in which those relationships arise.

\section{Gestational Surrogacy}

Just as artificial insemination raises questions of fatherhood, gestational surrogacy poses similar questions about motherhood. As an initial point, traditional surrogacy does not present such difficulties given that the surrogate not only carries the child, but she is also the biological mother,

\footnotetext{
167. Id. ("Wife encouraged Husband to be an active parent, and he was.").

168. Id. at 294 .

169. Id. at 295 ("The legislature . . cannot anticipate every contingency. . . [But] can, however, expect that when one of its orders . . is to be carried out, those who have that duty ... will discern its purpose and act in accordance with its essence if not necessarily its letter.").

170. Id. Further, the court held that

[g]iven the purposes of the statute, a writing should be satisfactory if it conveys in some manner that (1) the husband knows of the conception by artificial insemination, (2) the husband agrees to be treated as the lawful father of the child so conceived, and (3) the wife agrees that the husband will be treated as the lawful Id. father of the child.

171. Id. at 296
} 
often having been artificially inseminated with the sperm of the intended father. ${ }^{172}$ The expectation is that, after the child is born, the surrogate will surrender her parental rights in favor of the individual or couple who hired her. ${ }^{173}$ With gestational surrogacy, however, a surrogate agrees to carry a child with which she shares no biological relationship given that she is implanted with a fertilized egg, one that is often donated by a different woman entirely. ${ }^{174}$ Thus, with gestational surrogacy "the roles of genetic contribution and gestation can effectively be separated from each other and assumed by different individuals" ${ }^{175}$ - specifically, the surrogate herself, the egg donor, and the woman who intends to raise the child. ${ }^{176}$ As a result, questions can and do arise as to who is the child's legal mother.

\section{i. $\quad$ Egg Donor as Mother}

One way to answer that question would be simply to base the determination of motherhood on biological parenthood, with preference given to the egg donor. Courts in Ohio have done just that, holding "that the individuals who provide the genes of that child are the natural parents," and unless they have waived their rights "then they must be recognized as the natural and legal parents." ${ }^{777}$ One of the justifications provided by the court was that "given the relative certainty of DNA blood testing, such a foundation or test for parental identity would be simpler to apply and more certain in results." ${ }_{17}^{8}$ In 2007 , the Supreme Court of Ohio reaffirmed this position that, when it comes to gestational surrogacy, the legal mother is the egg donor. There, the court affirmed a lower court's ruling that gestational surrogacy contracts did not violate the state's "public policy against private agreements to forgo parental rights" given that the surrogate was not the biological

172. See Charles P. Kindregan, JR. \& Maureen McBrien, Assisted Reproductive TECHNOLOGY: A LAWYER's GUIDE TO EMERGING LAW AND SCIENCE 130-31 (2006).

173. See In re Baby M, 537 A.2d 1227, 1259 (N.J. 1988) (describing a traditional surrogacy contract as one in which "a perfectly fit mother was expected to surrender her newly born infant"); see also KINDGREGAN \& MCBRIEN, supra note 172, at $13_{1}$ ("[I]t is standard protocol for the surrogate to agree to surrender any resulting child for adoption after its birth to make the child available for adoption by the intended mother.").

174. In re Roberto d.B., 923 A.2d 115, 117 (Md. 2007) ("The gestational surrogacy context can involve anonymous sperm and egg donors, with the result that the child has no genetic relation to the gestational carrier or the intended parents."); KINDREGAN \& MCBRIEN, supra note 172 , at $132-33$.

175. Anne Reichman Schiff, Solomonic Decisions in Egg Donation: Unscrambling the Conundrum of Legal Maternity, 8o IOWA L. REV. $26_{5}, 26_{5}$ (1995).

176. See Hendricks, supra note ${ }_{15}$, at $43^{1}$ ("Law has lagged behind, trying to decide which mother (genetic mother, gestational mother, or intended mother) is the true mother.").

177. Belsito v. Clark, 644 N.E.2d 760,767 (Ohio Ct. C.P. 1994).

178. Id. at $766-67$. 
mother and thus "had no parental rights to contract away." ${ }^{179}$ Instead, according to the court, the child's mother was the egg donor. ${ }^{180}$

\section{ii. Gestational Surrogate as Mother}

A second approach is recognizing the gestational surrogate as the child's mother. In A.H.W. v. G.H.B., a 2000 case out of New Jersey, a married couple entered into an agreement with a surrogate whereby embryos created from the married couple's genetic material were implanted in the surrogate. ${ }^{181}$ Thus, the resulting child would be the biological child of the married couple, but would have gestated in the womb of the surrogate. The married couple petitioned for a pre-birth order listing them as the parents of the resulting child so that they could have their names listed on the birth certificate. ${ }^{182}$ The Superior Court of New Jersey, however, refused. Relying on the Supreme Court of New Jersey's previous rulings on traditional surrogacy, the court held that the gestational surrogate was the mother. ${ }^{183}$ Accordingly, pursuant to state adoption law, she could not legally surrender her maternal rights prior to the child's birth. ${ }^{18}$

In so doing, the court acknowledged the difference between traditional and gestational surrogacy-namely, unlike a gestational surrogate, a traditional surrogate is also the biological mother. ${ }^{185}$ Nonetheless, the court held that, because a gestational surrogate still manifests some aspects of motherhood, her parental rights could not be terminated prior to birth:

A bond is created between a gestational mother and the baby she carries in her womb for nine months. During the pregnancy, the fetus relies on the gestational mother for a myriad of contributions. A gestational mother's endocrine system determines the timing, amount and components of hormones that affect the fetus. The absence of any component at its appropriate time will irreversibly

179. J.F. v. D.B., 848 N.E.2d $873,878-79$ (Ohio Ct. App. 2006), aff'd, 879 N.E.2d 740 (Ohio 2007).

18o. Id. at 879 ("Flynn and Rice were the genetic providers, so Flynn and Rice were the children's parents under Ohio law.").

181. A.H.W. v. G.H.B., 772 A.2d 948, 949 (N.J. Super. Ct. Ch. Div. 2000).

182. Id.

183. Id. at 953. The Superior Court noted that "New Jersey regulations governing the creation of birth records state that the woman who gives birth must be recorded as a parent on the birth certificate." Id. (citing N.J.A.C. 8:2-1.4(a) (2005)).

184. Id. at 954; see also N.J. STAT. ANN. § 9:3-41 (e) (West 2013) ("A surrender by the birth parent of a child shall not be valid if taken within 72 hours of the birth of the child.").

185. A.H.W., 772 A.2d at 953 ("While [the parties] are correct that [the surrogate] will have no biological ties to the baby, their simplistic comparison to an incubator disregards the fact that there are human emotions and biological changes involved in pregnancy."). 
alter the life, mental capacity, appearance, susceptibility to disease and structure of the fetus forever. ${ }^{186}$

In 2010 , New Jersey would go one step further and hold that the infertile woman who hires a gestational surrogate can only become the legal mother through formal adoption, which can take place only after the child is born. ${ }^{187}$ In that case, a married couple hired a gestational surrogate who would carry the child, which was conceived using the husband's sperm and an egg from an anonymous donor. ${ }^{88}$ Once again the procuring couple sought a pre-birth order that would list them as the father and mother of the child. ${ }^{189}$ The court refused, ruling the gestational surrogate's "parental rights are deemed worthy of protection and thus stand in the way of the infertile wife's claim to automatic motherhood." $19^{\circ}$ Therefore, formal adoption was required to transfer parental rights from the gestational surrogate to the intended mother. ${ }^{19^{1}}$

\section{iii. Intended Mother as Mother}

The third and final approach to determining parental rights in cases involving gestational surrogacy takes a more flexible approach, focusing not on biology, but on intent. Under the intent test, the state determines which woman, prior to the child's conception, affirmatively intended to serve as the child's mother - that woman is then considered the child's legal mother. ${ }^{192}$ The seminal case in this area is the 1993 California case of Johnson v. Calvert. ${ }^{193}$ There, Mark and Crispina Calvert wished to have a child, but Crispina, due to an earlier hysterectomy, was unable to become pregnant. ${ }^{194}$ Nonetheless, because Crispina's ovaries remained capable of producing eggs, she and Mark were able to produce an embryo using in vitro fertilization. ${ }^{195}$ The couple then entered into an agreement with Anna Johnson, who agreed to serve as a

186. Id. "The gestational mother contributes an endocrine cascade that determines how the child will grow, when its cells will divide and differentiate in the womb, and how the child will appear and function for the rest of its life." Id.

187. In re Parentage of a Child by T.J.S. \& A.L.S., 16 A. $3 d$ 386, 388 (N.J. Super. Ct. App. Div. 2011 ).

188. Id. at $388-89$

189. Id. at 389

19o. Id. at 396 .

191. Id. at 391 ("[C] ontrary to the gender-neutral interpretation plaintiffs ask us to adopt, the plain language of the Act provides for a declaration of maternity only to a biologically-or gestationally_related female and requires adoption to render A.L.S. the mother of T.D.S.”).

192. Mary Patricia Byrn \& Lisa Giddings, An Empirical Analysis of the Use of the Intent Test to Determine Parentage in Assisted Reproductive Technology Cases, 5o Hous. L. REV. 1295, 1296 (2013) (explaining that under the intent test, "when a child is conceived via ART, the person(s) that intended to bring the child into the world and raise the child should be the child's legal parent(s)").

193. Johnson v. Calvert, $8_{5} 1$ P.2d 776, 782 (Cal. 1993) (en banc).

194. Id. at 778 .

195. Id. at 782 . 
gestational surrogate. ${ }^{196}$ Not long after Anna became pregnant with the Calvert's child, however, "relations deteriorated" between the couple and Anna, prompting both sides to file competing lawsuits seeking a declaration of motherhood. ${ }^{197}$ Anna claimed that she was the legal mother given that she was the gestational mother, whereas Crispina claimed motherhood through her genetic relationship to the child. ${ }^{198}$

The court began by noting that "California law recognizes only one natural mother, despite advances in reproductive technology rendering a different outcome biologically possible."199 Beyond that, however, the court could discern "no clear legislative preference" between biological motherhood and gestational motherhood given that California recognized both as "means of establishing a mother and child relationship." ${ }^{200}$ Thus, for situations in which the biological mother (in this case, Crispina) is someone other than the person who gestated the child (i.e., Anne), the court needed a means of deciding between the two presumptions. The court settled on intent, and specifically found that, "she who intended to procreate the childthat is, she who intended to bring about the birth of a child that she intended to raise as her own-is the natural mother under California law." ${ }^{201}$ Applying that standard to the facts, the Calverts emerged as the legal parents:

Mark and Crispina are a couple who desired to have a child of their own genetic stock but are physically unable to do so without the help of reproductive technology. They affirmatively intended the birth of the child, and took the steps necessary to effect in vitro fertilization.

But for their acted-on intention, the child would not exist. ${ }^{202}$

Although Anna tried to rely on the fathers' rights cases discussed earlier ${ }^{203}$ to bolster her claim to parenthood, the California court rejected those arguments, noting that they depend on a prior determination that Anna is in fact the child's mother: "Since Crispina is the child's mother under California law because she, not Anna, provided the ovum for the in vitro

196. Id. at 778 ("Mark, Crispina, and Anna signed a contract providing that an embryo created by the sperm of Mark and the egg of Crispina would be implanted in Anna and the child born would be taken into Mark and Crispina's home 'as their child.”).

197. Id.

198. See id. at 778,781 ("[W]e are left with the undisputed evidence that Anna, not Crispina, gave birth to the child and that Crispina, not Anna, is genetically related to him. Both women thus have adduced evidence of a mother and child relationship as contemplated by the Act.").

199. Id. at 781 . Although some amici had advocated that both women should be recognized as the child's mother, the court declined this invitation: "To recognize parental rights in a third party with whom the Calvert family has had little contact since shortly after the child's birth would diminish Crispina's role as mother." $I d$. at $781 \mathrm{n} .8$.

200. Id. at $781-82$.

201. Id. at 782 .

202. Id. ("The parties' aim was to bring Mark's and Crispina's child into the world, not for Mark and Crispina to donate a zygote to Anna. Crispina from the outset intended to be the child's mother.").

203. See supra Part II. 
fertilization procedure, intending to raise the child as her own, it follows that any constitutional interests Anna possesses in this situation are something less than those of a mother." ${ }_{204}$

Subsequently, California would extend the intent test to cover an intended mother who did not even have a biological relationship with the child in question. In In re Marriage of Buzzanca, a married couple, John and Luanne Buzzanca, contracted with a surrogate to carry an embryo that was produced using both sperm and an egg from anonymous donors. ${ }^{205}$ Despite the fact that the wife in that case, unlike in Calvert, could not claim a biological connection to the child, the court nonetheless had little difficulty in adjudicating her to be the legal mother in light of her intent: "Even though neither Luanne nor John are biologically related to [the resulting child], they are still her lawful parents given their initiating role as the intended parents in her conception and birth." ${ }^{\circ 66}$ Other courts have adopted similar intent standards for resolving questions of motherhood. ${ }^{207}$ At least one state has even enacted a statute that requires courts to take intent into consideration. Arkansas, for example, provides that a child born as a result of artificial insemination "shall be, for all legal purposes, the child of the woman giving birth, except in the case of a surrogate mother, in which event the child shall be that of ... [t] he biological father and the woman intended to be the mother." ${ }_{208}$

In sum, the emergence of gestational surrogacy has challenged the longstanding assumption that the woman who gives birth to a child must also be that child's legal mother. Instead, the law of gestational surrogacy, just like the law of artificial insemination, reveals that parenthood-be it motherhood or fatherhood-can no longer be based exclusively on biology. Instead, to

204. Johnson, $85^{1}$ P.2d at 786 . At the same time, the court did recognize the essential role that Anna played:

Although the gestative function Anna performed was necessary to bring about the child's birth, it is safe to say that Anna would not have been given the opportunity to gestate or deliver the child had she, prior to implantation of the zygote, manifested her own intent to be the child's mother.

Id. at 782 .

205. In re Marriage of Buzzanca, 72 Cal. Rptr. 2d 280, 282 (Cal. Ct. App. 1998).

206. Id. at 293 .

207. See, e.g., Raftopol v. Ramey, 12 A.3d 783, 793 (Conn. 2011) (allowing "an intended parent who is a party to a valid gestational agreement to become a parent without first adopting the children, without respect to that intended parent's genetic relationship to the children"). Relatedly, some courts have determined motherhood in cases involving gestational surrogacy by simply enforcing the terms of the surrogacy agreement. See, e.g., In re Paternity \& Custody of Baby Boy A., No. Ao7-452, 2007 WL 4304448, at *2 (Minn. Ct. App. Dec. 1 1, 2007) (denying gestational surrogate's petition to be declared the child's legal mother in light of the surrogacy agreement in which she averred that she had "no intention of having physical or legal custody or any parental rights, duties or obligations with respect to any child born of this gestational surrogacy process").

208. ARK. CODE ANN. $§ 9-10-201$ (c) (1) (2015). 
determine legal parentage, states are now actively looking at intent, asking who intended to parent the resulting child to determine legal parentage. As the next section demonstrates, however, some states treat parentage determinations for children born via assisted reproduction somewhat differently when the intended parents are the same sex.

\section{B. SAME-SEX PARENTAGE}

A similarly complicated question of parentage exists in cases of biological children being raised by same-sex couples. As Justice Kennedy noted in his majority opinion in Obergefell $v$. Hodges, "hundreds of thousands of children are presently being raised by [same-sex] couples"-couples who "provide loving and nurturing homes to their children, whether biological or adopted.” 209 Of course, for children who are jointly adopted by same-sex couples, parenthood determinations present little difficulty. For biological children being raised in same-sex families, however, the questions become more difficult. After all, two people of the same sex cannot currently conceive a child using only their genetic material. ${ }^{210}$ Thus, any biological child in a same-sex relationship will, at most, be the biological child of only one of the adults in that family. For that person's spouse or partner-that is, the person who lacks a biological relationship with the child-states have had to grapple with the question of that individual's parental rights. As a result, a number of state cases concerning same-sex couples have emerged, offering various insights into how the law treats parentage determinations of adults in samesex families who lack biological connections with their children. ${ }^{211}$

209. Obergefell v. Hodges, 135 S. Ct. 2584, 2600 (2015)

210. See John A. Robertson, Gay and Lesbian Access to Assisted Reproductive Technology, 55 CASE W. RES. L. REV. 323, 324-25 (2004) ("Homosexuals may also seek ARTs for infertility, but more often they use them because they cannot reproduce with their partners or others of the same sex."). As advances in assisted reproduction continue, however, even this may change. Indeed, as Professor Michael Boucai has noted,

in vitro gameteogenesis (IVG) [is] a process successfully tested in mice, whereby a sperm cell is created from an egg cell-or, alternatively, an egg cell is created from a sperm cell. IVG could allow same-sex couples to have offspring biologically related to both partners and, by eliminating the need for third-party gametes, enable them "to reproduce in a manner similar to fertile straight couples."

Michael Boucai, Is Assisted Procreation an LGBT Right?, 2016 WIS. L. REV. 1065, 1093 (quoting Sonia M. Suter, In Vitro Gametogenesis: Just Another Way to Have a Baby?, 3 J.L. \& BIOSCIENCES 87, $103(2016))$.

211. Currently, all such cases have involved lesbian couples, which is not surprising given the relative ease with which two women can conceive a child using assisted reproduction. See NeJaime, supra note 14 , at 1200 ("With the rise of alternative insemination in the late 1970 s and 1980 , the number of lesbian couples starting families skyrocketed."). Same-sex male couples, on the other hand, who desire children with a biological connection to one of the fathers would have to use some version of surrogacy, which is exponentially more expensive, more complicated, and thus more unusual. See Robertson, supra note 210 , at $35^{\circ}$ ("[A] surrogate mother is essential for gay male reproduction to occur ....”). 
For those same-sex couples who are married, one option is to simply apply the marital presumption, which as discussed earlier, provides that the husband of a woman who has been artificially inseminated is, unless he did not consent, deemed the legal father. ${ }^{212}$ Disaggregating the presumption from its gendered language would lead to the same result for the female spouse of a woman who, while married, conceived a child via artificial insemination. Indeed, that is exactly what at least two courts have done. ${ }^{213}$ For example, in Gartner v. Iowa Department of Public Health, a 2013 decision by the Iowa Supreme Court, ${ }^{21}$ Melissa and Heather Gartner married just a few months after Iowa legalized same-sex marriage. ${ }^{215}$ Heather became pregnant using artificial insemination, but the state Department of Health refused to list Melissa's name on the birth certificate given that she had not formally adopted the child. ${ }^{216}$ Iowa's marital presumption provides that "[i]f the mother was married at the time of conception, birth, or at any time during the period between conception and birth, the name of the husband shall be entered on the certificate." ${ }_{17}$ The Department, however, believed this statute to be inapplicable, noting that " $[\mathrm{t}]$ he system for registration of births in Iowa currently recognizes the biological and 'gendered' roles of 'mother' and 'father,' grounded in the biological fact that a child has one biological mother and one biological father." 218

The Supreme Court of Iowa rejected the Department's interpretation, ruling that an interpretation that applies the marital presumption to oppositesex but not same-sex couples would violate the equal protection guarantee of the Iowa Constitution. ${ }^{219}$ First, the court found that both same-sex and opposite-sex couples were similarly situated in this regard: "The Gartners are in a legally recognized marriage, just like opposite-sex couples. The official recognition of their child as part of their family provides a basis for identifying and verifying the birth of their child, just as it does for opposite-sex couples." ${ }^{220}$ Thus, according to the court, to treat same-sex couples differently was to discriminate on the basis of either sex or sexual orientation, either of which would incur intermediate scrutiny. ${ }^{221}$ The court went on to hold that the state had failed to prove that its gendered interpretation of the marital

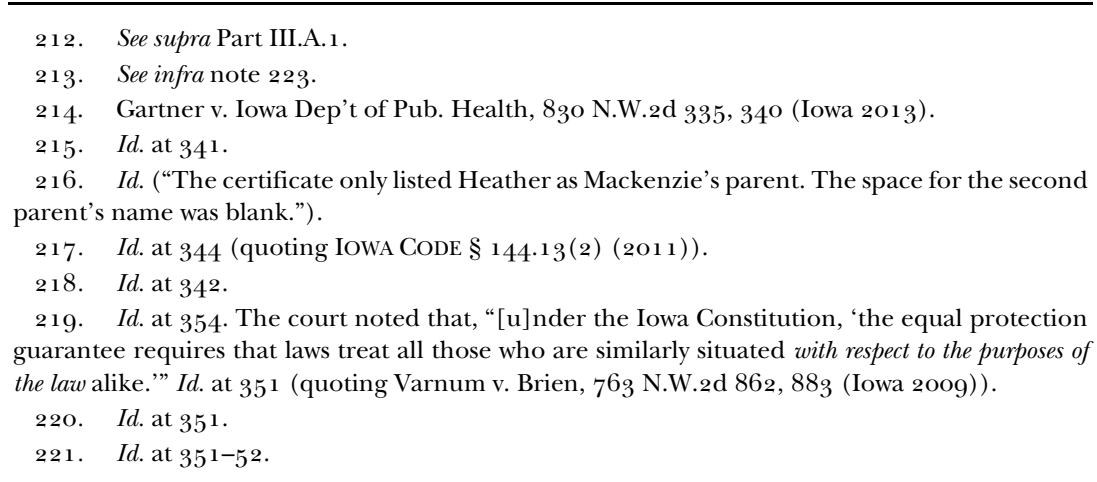


presumption was substantially related to any important governmental objective, holding that "[i]t is important for our laws to recognize that married lesbian couples who have children enjoy the same benefits and burdens as married opposite-sex couples who have children." ${ }_{222}$ In ruling as it did, the court also noted that "the only explanation for not listing the nonbirthing lesbian spouse on the birth certificate is stereotype or prejudice." 223

Other states, however, have strictly adhered to the gendered terms of the marital presumption. ${ }^{22}$ In 2016, for example, the Supreme Court of Arkansas upheld "the Arkansas Department of Health's (ADH) refusal to issue birth certificates for minor children of married female couples showing the name of the spouse of the mother." ${ }_{225}$ In ruling, the court analyzed the statute in question, which provides that "if the mother was married at the time of either conception or birth or between conception and birth the name of the husband shall be entered on the certificate as the father of the child." ${ }^{26}$ As an initial matter, the court found that "[t]he purpose of the statutes is to truthfully record the nexus of the biological mother and the biological father to the child." ${ }_{227}$ Accordingly, the court ruled that it must "construe it just as it reads, giving the words their ordinary and usually accepted meaning in common language." ${ }^{228}$ The court then turned to Webster's dictionary, noting "that 'husband' is defined as 'a married man." ${ }_{229}$ In ruling as it did, the court rejected the same-sex couples' equal protection challenge, merely noting that "the female spouse of a biological mother . . . does not have the same biological nexus to the child that the biological mother or the biological

222. Id. at 353. Specifically, in terms of birth certificates, "married lesbian couples require accurate records of their child's birth, as do their opposite-sex counterparts. The distinction for this purpose between married opposite-sex couples and married lesbian couples does not exist and cannot defeat an equal protection analysis." Id. at $35^{1}$.

223. Id. at 353. The Supreme Court of Arizona recently reached a similar result, holding that the state's marital presumption, which "by its terms only applies to males," must likewise protect the parental rights of a lesbian spouse. McLaughlin v. Jones, 401 P.3d 492, 496 (Ariz. 2017) ("[I]n the wake of Obergefell, excluding [wife of woman who bore a child via artificial insemination] from the marital paternity presumption violates the Fourteenth Amendment.").

224. In addition to the Arkansas case, discussed infra, Florida has likewise taken a similar approach to restricting the right of lesbian couples to rely on the marital presumption. See NeJaime, supra note 14, at 1243-44 ("A Florida statute provides that, "[i]f the mother is married at the time of birth, the name of the husband shall be entered on the birth certificate as the father of the child,' but the state has refused to apply this statutory provision to married lesbian couples." (footnote omitted) (quoting FLA. STAT. $\$ 382.013(2)$ (a) (2015))).

225. Smith v. Pavan, 505 S.W.3d 169, 172 (Ark. 2016), rev'd sub nom. Pavan v. Smith, 137 S. Ct. 2075 (2017).

226. Id. at 175 (quoting ARK. CODE ANN. § 20-18-401 (f) (1) (2012)).

227. Id. at 180 .

228. Id. at 177 .

229. Id. at $177-78$ (quoting Husband, WEBSTER's THIRD NEW INTERNATIONAL DICTIONARY $(2002))$. 
father has." ${ }_{30}$ Thus, concluded the court: "It does not violate equal protection to acknowledge basic biological truths." ${ }^{231}$

Beyond the parental rights arising from same-sex marriage, states have also had to decide the parental status of unmarried individuals vis-à-vis the biological children of their same-sex partners. In Elisa B. v. Superior Court, for instance, the Supreme Court of California ruled that the former partner of a woman who had conceived twins via artificial insemination was the legal parent of those children. ${ }^{232}$ The court arrived at this conclusion despite the fact that the woman in question, Elisa B., had no biological relationship to the children, and the two women were never married.233 The court based its decision on a California statute that declared "a man is presumed to be the natural father of a child if ' $[\mathrm{h}] \mathrm{e}$ receives the child into his home and openly holds out the child as his natural child." ${ }_{234}$ Despite the statute's use of gendered language, state law also provided that, when attempting to establish a mother-child relationship, "the provisions of this part applicable to the father and child relationship apply." ${ }_{235}$ In light of that statutory directive, and given the active role Elisa had played in the twins' early life, the court had little difficulty in finding that Elisa was a legal parent:

Elisa is a presumed mother of the twins . . . because she received the children into her home and openly held them out as her natural children, and that this is not an appropriate action in which to rebut the presumption that Elisa is the twins' parent with proof that she is not the children's biological mother because she actively participated in causing the children to be conceived with the understanding that she would raise the children as her own together with the birth mother, she voluntarily accepted the rights and obligations of parenthood after the children were born, and there

230. Id. at 181 . In support, the court quoted from the Supreme Court's decision in Tuan Anh Nguyen v. I.N.S., 533 U.S. 53, 73 (2001): "[T] f fail to acknowledge even our most basic biological differences ... risks making the guarantee of equal protection superficial, and so disserving it." Id.

231. Id. The same-sex couples subsequently appealed to the U.S. Supreme Court, which took the rare step of issuing a summary reversal. In ruling, however, the Court said nothing about constitutional parenthood or even substantive due process, but instead seemed to rely on an equal protection argument, limiting its holding to the narrow ground that, by making the marital presumption available to married opposite-sex couples, Arkansas could not withhold that same benefit from married same-sex couples: "The State uses [the marital presumption] to give married parents a form of legal recognition that is not available to unmarried parents. Having made that choice, Arkansas may not, consistent with Obergefell, deny married same-sex couples that recognition.” Pavan v. Smith, 137 S. Ct. 2075, 2078-79 (2017).

232. Elisa B. v. Superior Court, 117 P.3d 66o, 670 (Cal. 2005).

233. Id. at 663 .

234. Id. at 667 (quoting CAL. FAM. CODE $§ 7611$ (d) (Deering 2005)). California subsequently amended the statute to make it gender neutral. See A.B. 1403, 2013-2014 Leg., Reg. Sess. (Cal. 2013).

235. Elisa B., 117 P.3d at 665 (quoting CAL. FAM. CODE $\$ 765^{\circ}$ (Deering 2005)). 
are no competing claims to her being the children's second parent. ${ }^{236}$

Thus, the court held that Elisa was a legal parent not because she was biologically related to the child or even that she was married to the mother, but instead because she was the intended parent of the twins and, in addition, had affirmatively acted as a parent.

In other states, however, courts have refused to recognize same-sex partners as legal parents even when faced with overwhelming evidence of that person's intent to serve in that role. For instance, the Supreme Court of Wisconsin remanded a case with facts similar to that of Elisa B. to determine the parental rights of the same-sex partner. ${ }^{237}$ Even then, the court made clear that, at most, the partner would have to prove that "she has a parent-like relationship with the child and that a significant triggering event justifies state intervention in the child's relationship with a biological or adoptive parent." ${ }_{38}^{8}$ In other words, the court seemed to assume that a samesex partner in her position had no claim to legal parenthood but perhaps could qualify under some secondary status.

Thus, some states have seized upon the lack of standards relating to constitutional parenthood to openly discriminate against the same-sex parents of children conceived using artificial inseminations. ${ }^{239}$ Courts in these states refuse to apply state marital presumptions to same-sex spouses and refuse to consider findings of parental intent. Indeed, of all the recent changes to the American family, it appears that the legalization of the samesex marriage has prompted overt forms of discrimination when it comes to how the states have defined "parent." ${ }^{\circ} 4^{\circ}$ One of the biggest contributors to the states' ability to discriminate in this manner is the lack of any guidance from the Supreme Court on the constitutional limits relating to parental identity.

\section{THE PSYCHOLOGICAL PARENT}

As the previous sections illustrate, when it comes to assisted reproduction and same-sex families, parental identity turns heavily on who, prior to the child's conception, intended to parent the child. ${ }^{24}$ The realities of family and child-rearing, however, are such that regardless of who was initially the

\footnotetext{
236. Id. at 670 .

237. See In re Custody of H.S.H.-K., 533 N.W.2d 419, 421-22, 425-3o (Wis. 1995).

238. Id. at 421 (emphasis added).

239. See NeJaime, supra note 14, at 1245 ("In states that remain hostile to LGBT equality, resistance to application of the marital presumption to same-sex couples surely represents further enactment of anti-LGBT sentiment."); supra note 222 and accompanying text.

240. See Christopher R. Leslie, The Geography of Equal Protection, 101 MINN. L. REv. 1579,1614 $(2017)$ ("The family law regimes of many states are infused with anti-gay prejudice. ... Although Obergefell has extended the constitutional right to marry to include same-sex couples, many states continue to discriminate against gay families.").

241. See supra Part III.A.
} 
intended parent(s), the actual individual(s) who function as the child's parent(s) can change over that child's life-a phenomenon one scholar refers to as "Mid-Life Parental Switches." ${ }_{42}$ This is especially true today given that divorce is not only more common than it was earlier in our nation's history, but there are also increased patterns of "divorce, cohabitation, and remarriage," ${ }_{243}$ all of which give rise to novel questions of parenthood. As Nancy Dowd has described, "[m] ultiple parents . . . are a social reality[,] but not a legal category." ${ }_{244}$ Thus, courts have been increasingly called upon to decide whether someone can become a parent simply by functioning as one. In attempting to label this form of parentage, courts have used a variety of terms including psychological parent, quasi-parent, and parent by estoppel. ${ }^{245}$

Initially, it is important to note that courts have largely resisted such claims. Consider, for instance, the case of Donald Merkel, who lived with his girlfriend and her son for seven years..$^{2}{ }^{6}$ Merkel, despite being neither the legal nor the biological father, had nonetheless assumed responsibility for helping raise the child. ${ }^{247}$ Thus, when the relationship between the two adults ended, Merkel filed for visitation, claiming that he was a de facto parent. ${ }^{24}$ The lower court, however, dismissed his petition, and the Supreme Court of South Dakota affirmed. In ruling, the court stated that "[b]efore a parent's right to custody over his or her own children will be disturbed in favor of a nonparent a clear showing against the parent of 'gross misconduct or unfitness, or of other extraordinary circumstances affecting the welfare of the child' is required." ${ }_{249}$ Given that Merkel failed to make any such showing, his petition was dismissed.250 In holding as it did, the court made clear that "an award cannot be made to [nonparents] simply because they may be better

242. Buss, supra note 45 , at 676 ("In these cases, a child classically lives with one or both biological parents for some period of her life, but at some point, others assume much or all of the parents' child rearing responsibilities.").

243. McClain, supra note 38, at 55; see also NeJaime, supra note 14, at 1196 ("With more divorces came more second marriages. As divorced parents formed blended families-and other unmarried women with children married-stepparents assumed parental roles."); Linda C. McClain \& Daniel Cere, Introduction, in WhAT Is PARENTHOOD: CONTEMPORARY Debates ABOUT THE FAMILY, supra note 38 , at 1 ("[D] emographic reports suggest[] a shift away from marriage and toward alternative family forms ....”).

244. Nancy E. Dowd, Multiple Parents/Multiple Fathers, 9 J.L. \& FAM. STUD. 231, 231 (2007).

245. See, e.g., LP v. LF, 338 P.3d 9o8, 909, 920-21 (Wyo. 2014) (using "parentage by estoppel”); H.M. v. E.T., 930 N.E.2d 206, 211 (N.Y. 2010) (using “quasi-parents”); V.C. v. M.J.B., $74^{8}$ A.2d 539, 549 (N.J. 2000) (using the term "psychological parent" throughout the opinion).

246. Cooperv. Merkel, 470 N.W.2d 253, 254 (S.D. 1991).

247. Id.

248. Id.

249. Id. at 255 (quoting Langerman v. Langerman, 336 N.W.2d 669, 670 (S.D. 1983 )).

25 . Id. at $25^{6}$ ("Donald's motion for visitation contained no charge that Tamera was unfit or guilty of misconduct nor was there any allegation of unusual circumstances. The motion merely alleged that Donald helped raise Tamera's son and that having assumed part of that responsibility he should be granted the opportunity to visit the boy."). 
custodians. ${ }^{25^{1}}$ South Dakota is by no means an anomaly in this regard. ${ }^{252}$ As Professor Robin Fretwell Wilson points out, "[v]ery few [jurisdictions] permit unmarried cohabitants to initiate actions for custody or visitation." ${ }^{253}$

Even in cases involving married couples, stepparents have likewise encountered resistance when trying to gain parental rights over the children they helped raise. For example, Nicholas Gansner and Miki Mancine married a few months after Mancine's adoption of her son, William, became final. ${ }^{254}$ At this time, William was not quite one year old, and Mancine had adopted him as a single parent. ${ }^{255}$ Despite his intention to adopt William, Gansner never did so. ${ }^{25}$ Nonetheless, he held himself out as William's father and, according to his testimony, served as the child's primary caregiver. ${ }^{257}$ In 2010 , Mancine filed for divorce, prompting Gansner to move for sole custody of William. ${ }^{25}{ }^{8}$ In response, Mancine successfully moved to dismiss his petition given that he was not the child's legal parent.259 Gansner appealed, claiming "that he acted as William's father in every way and has developed a bond with William such that he should be recognized as William's 'equitable parent."”26o The Illinois appellate court, however, rejected his argument, noting that the state had not recognized equitable parentage and that Gansner, despite knowing "at all times that he would have to formally adopt William in order to be his legal parent," failed to do so. ${ }^{261}$

Although the minority approach, some jurisdictions have been more sympathetic to such claims. In fact, as David Meyer describes, "[a] growing number of courts and legislatures now permit adults who assumed the functional role of a parent to preserve their relationship with a child" despite objections from the child's legal parent. ${ }^{262}$ Colorado did just that in 2004 when it awarded parental rights to a party who not only lacked a legal relationship with the child in question but who was not even married to the

251. Id. at 255 .

252. See, e.g., State ex rel. Ephraim H. v. Jon P., No. A-04-1488, 2005 WL 2347727 , at * 3 (Neb. Ct. App. Sept. 27, 2005) (awarding custody to biological father and not step-father despite the fact that biological father had been "mostly absent from" the child's life).

253. Robin Fretwell Wilson, Undeserved Trust: Reflections on the ALI's Treatment of De Facto Parents, in RECONCEIVING THE FAMILY: CRITIQUE ON THE AMERICAN LAW INSTITUTE's PRINCIPLES OF THE LAW OF FAMILY DiSSOLUTION, supra note 45, at 9o, 98 (footnote omitted).

254. In re Marriage of Mancine and Gansner, 9 N.E.3d 550, 555 (Ill. App. Ct. 2014).

255. Id. ("Because Miki had already started the adoption process of William as a single parent before she met Nicholas, Miki and Nicholas were advised by the adoption agent to finish the process of Miki's adoption of William, and then for Nicholas to adopt William as a stepparent after the parties' marriage.").

$25^{6 .} \quad I d$. at 554 .

257. Id. at $55^{6}$

$25^{8 .} \quad I d$.

259. Id.

260. Id. at 565 .

261. Id. at 568 .

262. Meyer, supra note 45 , at $5^{\text {o. }}$ 
parent of the child. ${ }^{263}$ Cheryl Ann Clark and Elsey Maxwell McLeod were in a committed relationship for eleven years. ${ }^{26} 4$ Although the two never married, they did discuss having children together. ${ }^{26}$ Eventually, they settled on adoption, with Clark adopting a child from China. ${ }^{266}$ Because China would not permit adoption by same-sex couples, the adoption was by Clark only. ${ }^{267}$ Nonetheless, the two traveled to China together to bring the child home and subsequently represented themselves publicly as the child's two parents. ${ }^{268}$ Six years after the adoption, the relationship between Clark and McLeod ended, and Clark attempted to limit McLeod's visitation with the child. ${ }^{269}$ McLeod, in turn, petitioned for equal parenting time. ${ }^{270}$ The Colorado court held that McLeod, despite being neither a natural nor adoptive parent, was nonetheless a psychological parent, which the state defined as "someone other than a biological parent who develops a parent-child relationship with a child through day-to-day interaction, companionship, and caring for the child." ${ }^{271}$ In light of that recognition, and concerned with the harm that would befall the child should McLeod's parental rights be terminated, the court granted McLeod's petition, awarding her joint parental responsibilities over the child. ${ }^{272}$

Similarly, in 2004, New Jersey held that a neighbor who had, with the consent of the child's legal custodian, been "involved in every aspect of [the child's] life from four months old to four and one-half years old," was a psychological parent and, as such, had standing to petition for custody. ${ }^{273}$ Just like the court in Colorado, the court was primarily motivated by the harm that would befall the child should the relationship be terminated: "[A]t the heart of the psychological parent cases is a recognition that children have a strong interest in maintaining the ties that connect them to adults who love and

\footnotetext{
263. In re E.L.M.C., 100 P.3d 546, 562 (Colo. App. 2004).

264. Id. at 549 .

265. Id.

266. $I d$.

267. $I d$.

268. Id. For example, the adoption announcement stated: "[E.L.M.C.] was born in the Hunan providence of the People's Republic of China. She lived the first six months of her life in the Yue Yang Children's Welfare Home in Yue Yang, China. She now lives with two adoring moms." Id.

269. Id. at $55^{\circ}$

270. Id.

271. Id. at 562, 559 (quoting In re Marriage of Martin, $4^{2}$ P.3d 75, 77-78 (Colo. App. 2002)).

272. Id. at 562 ("Accordingly, we conclude that, in light of the overwhelming evidence showing McLeod had become a psychological parent, whom E.L.M.C. recognized almost from birth, the curtailment and later termination of McLeod's parental responsibilities in Clark's proposed parenting plan threatened emotional harm to E.L.M.C. ....").

273. P.B. v. T.H., $8_{5} 1$ A.2d 780,790 (N.J. Super. Ct. App. Div. 2004).
} 
provide for them." 274 It is important to note, however, that in these cases, the courts used psychological parenthood merely as a means for awarding parental rights, without necessarily ruling that these individuals have attained the status of legal parenthood. ${ }^{275}$

Some have suggested, however, that perhaps psychological parentage should instead be viewed as an additional path to legal parenthood. The American Law Institute ("ALI") adopted this approach in its Principles of the Law of Family Dissolution ("Principles"). ${ }^{276}$ Published in 2002, the purpose of the Principles was to propose "how the law should respond to changes in family forms over the last half century." ${ }_{277}$ Specifically, the Principles attempt to answer the question "Who is a parent?" ${ }_{28}^{8}$ In response, the Principles recognize three categories of parentage. ${ }^{279}$ The first is legal parents, a term that applies to those who are currently classified-typically via a biological relationship or through formal adoption-as a parent under state law. ${ }^{280}$ The Principles, however, do not stop there, but in an attempt to broadly recognize psychological parentage, propose an additional two categories of parenthood- "parents by estoppel" and "de facto parents."

A parent by estoppel is one who, with the permission of the child's legal parent, lived with the child for at least two years (or, for children less than two years of age, since the child's birth) and assumed "full and permanent responsibilities as a parent." ${ }^{281}$ In contrast, a de facto parent is one who for at least two years, either as a result of an agreement with the legal parent or because of that parent's "complete failure or inability . . . to perform caretaking functions," lived with the child and voluntarily performed caretaking functions equal to the "parent with whom the child primarily lived." ${ }^{282}$ Under the Principles, a parent by estoppel is afforded all the same

274. Id. at 785 (quoting V.C. v. M.J.B., 748 A.2d 539, $55^{\circ}$ (N.J. 200o)); see also Scott v. Scott, 147 S.W.3d 887, 890 (Mo. Ct. App. 2004) (awarding third-party custody to former partner of biological mother given that "to remove him from her custody would be detrimental to his welfare").

275. See Riepe v. Riepe, 91 P.3d 312, 317 (Ariz. Ct. App. 2004) ("A person standing in loco parentis to a child is not a 'parent,' does not enjoy parental rights, and therefore does not become an 'additional parent[]' ...."); Meyer, supra note 45 , at $5^{\circ}$ ("[A]lthough they may be permitted to preserve a 'parent-like' relationship with the child in this way, these care givers continue to occupy the status of a nonparent.").

276. See AM. LaW InSt., PRinciples of the LAW OF Family Dissolution: ANAlysis and RECOMMENDATIONS $5^{-6,117-20}$ (2002) [hereinafter PRINCIPLES].

277. Michael R. Clisham \& Robin Fretwell Wilson, American Law Institute's Principles of the Law of Family Dissolution, Eight Years After Adoption: Guiding Principles or Obligatory Footnote?, 42 FAM. L.Q. 573, 573 (2008).

278. Sarah H. Ramsey, Constructing Parenthood for Stepparents: Parents by Estoppel and De Facto Parents Under the American Law Institute's Principles of the Law of Family Dissolution, 8 DUKE J. GENDER L. \& POL'Y 285, 291 (2001).

279. PRINCIPLES, supra note $276, \S 2.03(1)(\mathrm{a})-(\mathrm{c})$.

280. $\quad I d . \S 2.03(1)(\mathrm{a})$.

281. Id. $\$ 2.03(1)$ (b) (iv).

282. Id. $\$ 2.03(1)$ (c) (ii). 
rights and responsibilities as a legal parent. ${ }^{283}$ De facto parents, on the other hand, despite being "entitled to preserve established parenting roles alongside the child's other parents," ${ }_{28} 4$ are afforded a secondary status under the Principles. For instance, the Principles prohibit courts from awarding de facto parents "the majority of custodial responsibility" if a legal parent or a parent by estoppel objects. ${ }^{285}$

The ALI's expansive definition of parenthood is, to put it mildly, quite controversial and has prompted a number of legal scholars to voice their concerns. ${ }^{286}$ However, despite those objections, as one scholar has observed, "several states have begun to move tentatively in that direction." ${ }_{28}$ Maryland, for example, recently relied on the Principles as just one example of the growing "decisional and statutory law of other jurisdictions" that prompted it to reverse its previous stance "and recognize de facto parenthood." 288 Similarly, the Supreme Court of Rhode Island ruled that a de facto parent could seek visitation, noting "that our position here is in harmony with the principles recently adopted by the American Law Institute.” ${ }^{289}$

Nonetheless, no jurisdiction has explicitly adopted the ALI's approach. However, with the proliferation of non-traditional child-rearing practices and the corresponding enlargement of the pool of parental candidates, more and more courts will likely face situations requiring them to consider, if not the Principles itself, the underlying issue of when "legal strangers" can claim parental rights. Indeed, the increasing awareness of psychological parentage, just like advances in artificial insemination and the formal recognition of same-sex families, continues to complicate state determinations of parentage. With no guidance from the nation's highest court, however, states are likely to continue resolving claims of parental identity using disparate solutions,

283. See Meyer, supra note 45 , at $5^{1}$ ("Thus, in a custody dispute between an adoptive parent and a parent by estoppel, neither would enjoy any legal preference over the other.").

284. Id.

285. See PrINCIPLES, supra note 276, § 2.18(1) (a); see also id. § 2.o9(2) (entitling legal parents and parents by estoppel, but not de facto parents, to a presumption of decisionmaking authority). 286. See, e.g., Buss, supra note 45 , at 643 ("The ALI's custodial scheme ... is problematic in several interrelated respects."); Wilson, supra note 253, at 93 (criticizing the ALI's "ballooning definition of parent"); see also Linda C. McClain, Love, Marriage, and the Baby Carriage: Revisiting the Channelling Function of Family Law, 28 CARDOZO L. REV. 2133,2176 (2007) ("[T] he ALI Principles have drawn criticism for proposing to recognize certain categories of nonbiological parenthood."). 287. See Meyer, supra note 45 , at $5^{1}$.

288. Conover v. Conover, $14^{6}$ A.3d 433, $45^{1}$ (Md. 2016) (emphasis omitted) (overruling Janice M. v. Margaret K., 948 A.2d 73 (Md. 2008)).

289. Rubano v. DiCenzo, 759 A.2d 959, 974-75 (R.I. 20oo) ("There, the ALI has recognized that individuals who have been significantly involved in caring for and supporting children and for whom they have acted as parents may obtain legal recognition of their parental rights to visitation and custody."); see also E.N.O. v. L.M.M., 711 N.E.2d 886, 891 (Mass. 1999) (citing the Principles in support of the court's decision to treat a biological mother's former partner as a de facto parent and thus award visitation). 
thus further conditioning a person's ability to claim constitutional protections based on their state citizenship.

\section{DEFInING Twenty-First Century ParenthoOd}

Constitutional rights are expected to apply uniformly throughout the United States. ${ }^{20}$ Indeed, as Professor Jeffrey Parness points out, "[t]here is general uniformity nationwide, per federal cases, among the criminally accused, gun toters, and abortion seekers who possess and enforce the same federal constitutional rights." ${ }^{21}$ Absent from that list, however, are parentsan omission that is fully warranted given that the definition of parent currently varies from state to state. ${ }^{292}$ Thus, the constitutional rights that flow from parenthood are being applied unevenly throughout the country, frequently in a way that "reflects and perpetuates inequality based on gender and sexual orientation." 293 It is, of course, entirely unreasonable to expect a single, uniform definition for determining who qualifies as a parent. As Professor Buss explains: "Any simple formula-whether based on history, biology, or biology plus some relationship-that purports to establish to whom parental rights belong will fail, in some circumstances, to account for those who constitute a child's familial core." ${ }^{94}$ Accordingly, "[a] constitutional protection reduced to any such formula will therefore disserve the important child-rearing interests the Constitution should be construed to protect." ${ }^{295}$

At the same time, however, "it is the nature of a constitution to set outer limits to legislative competence." ${ }_{29}^{6}$ Indeed, the Supreme Court has already indicated through the fathers' rights cases that there are in fact some lines the states cannot cross when it comes to defining parenthood. ${ }^{297}$ For instance, as David Meyer has pointed out, it seems unlikely that a state could constitutionally restrict parenthood to adults who meet all three of the parental criteria- "genetic ties, emotional bonding, and traditional social

\footnotetext{
29o. Wayne A. Logan, Contingent Constitutionalism: State and Local Criminal Laws and the Applicability of Federal Constitutional Rights, $5^{1}$ WM. \& MARY L. REV. 143, 169 (2009) ("[F]ederal constitutional rights are understood to extend equally across the land ....").

291. Parness, supra note 45 , at 968 (footnotes omitted).

292. See supra Part III.

293. NeJaime, supra note 45, at 2268; see also McClain, supra note 39, at 54 ("Family law in the United States is not uniform. Among the states are salient differences, sometimes along the lines of red versus blue states, with red states more closely embracing integrative parenthood and rejecting forms of family diversity.").

294. Buss, supra note 45 , at 662 .

295. Id.

296. Marc A. Franklin, The Origins and Constitutionality of Limitations on Truth as a Defense in Tort Law, 16 STAN. L. REV. 789,798 (1964).

297. See supra Part II.
} 
consensus"-that seemed to emerge from those cases. ${ }^{29}{ }^{8}$ It is the position of this Article, however, that the Constitution compels the imposition of additional limits on the states' ability to define parenthood. That is not to suggest, however, that the approaches the states have taken during the Court's silence should be disregarded. Instead, there is much in those approaches to assist the Court in reformulating the test of constitutional parenthood in light of these new paths to parentage.

What follows, then, are suggestions on how the Court might take what it has already said on the subject of parental identity-in essence, the biology plus doctrine 299 - and update the doctrine to better reflect the reality of 21 stcentury parenthood, $3^{\circ 0}$ using the intervening state approaches as a guide. Specifically, the remainder of this Part proposes a more contemporary definition of constitutional parenthood-one that helps delineate the boundaries states cannot cross so as to better protect these new forms of parentage from invidious discrimination. At the same time, however, this proposal likewise clarifies those areas that should remain subject to state legislation. The three key tenets of the proposal are: (1) intentional parents should be afforded the same opportunity as biological parents to develop a constitutionally protected liberty interest in their children; (2) functional parenthood should continue to be required in order for that opportunity to ripen into a fully protected constitutional right; and (3) psychological parentage, although subject to recognition by the states in ways that do not infringe the constitutional protections of legal parents, should not alone qualify as a path to constitutional parenthood.

\section{A. BIology Plus InTENT}

In Lehr, the Court put forth the biology plus doctrine for determining parental identity. ${ }^{301}$ As previously discussed, biology is a strong factor in determining the parents of a child. Thus far, the Court has not been called upon to address whether legal parentage can, absent formal adoption, automatically flow to one who does not have a biological connection. Of course, the fact that the Court would not yet have gone beyond biology in defining parental identity is in no way surprising. As its name makes clear, the biology plus doctrine, as a starting point, assumes the existence of a biological connection. Moreover, each of the five fathers' rights cases that developed the biology plus doctrine were initiated by biological fathers seeking constitutional protections primarily on the basis of biological connection.

298. Meyer, supra note 45 , at 62 ("[I] t seems reasonably clear that denying parental status at least to adults meeting all three of these markers would cross the line.").

299. See supra notes 108-12 and accompanying text.

3oo. As Professor Jennifer Hendricks has argued, "[t] he emergence of new technology does not mean that courts must reinvent the law of parental status from scratch." Hendricks, supra note 15 , at 467 .

301. See supra notes 100-12 and accompanying text 
This Article proposes, as an initial step, that biology continue to provide an individual an "inchoate interest" ${ }^{02}$ in his or her child-an interest that, subject to the functional parenthood requirement, ${ }^{303}$ could very well ripen into a fully protected liberty interest. However, biology alone cannot be the sole basis for providing that opportunity. Indeed, if biological parenthood were the only category that could conceivably qualify as constitutional parenthood, then egg and sperm donors would have more protections than the intentional parents on whose behalf the donations were made. A sperm donor, for example, would have more rights vis-à-vis a child conceived using his sperm than would the man who is married to the child's mother and who always intended to raise the child as his own. To solve this problem, the standard for constitutional parenthood must also take into consideration the concept of intentional parenthood-a concept that, as discussed earlier, the states have already relied upon in a variety of contexts to determine legal parentage..$^{04}$ Indeed, just as it has become a key component to parental identity at the state level, intent must likewise factor into the determination of constitutional parenthood.

However, like biological parenthood, intentional parenthood alone should not be dispositive. If intent alone were sufficient to bestow parental rights, then situations would arise where a genetic parent who was never the intended parent, but whose contributions went beyond mere gamete donation, would automatically lose all parental rights. For instance, a traditional surrogate, who carries her own biological child yet is expected to surrender that child at birth to the intended parents, would lose the ability to ever change her mind if intent were the controlling principle. ${ }^{305}$ In other words, just as the rapidly evolving family necessitates a revised definition of constitutional parenthood, it likewise cautions that future definitions not be too restrictive. As Professor Linda C. McClain noted, "[t]he demographic changes of the past century make it difficult to speak of an average American family." ${ }^{\circ 06}$ She is, of course, correct; and as society continues to evolve and reproductive technology continues to grow, our understanding of the average family is likely to become even more elusive. Given then that future incarnations of the family are likely to involve modes of conception and childrearing that we cannot currently anticipate, flexibility is key when defining "parenthood." 307

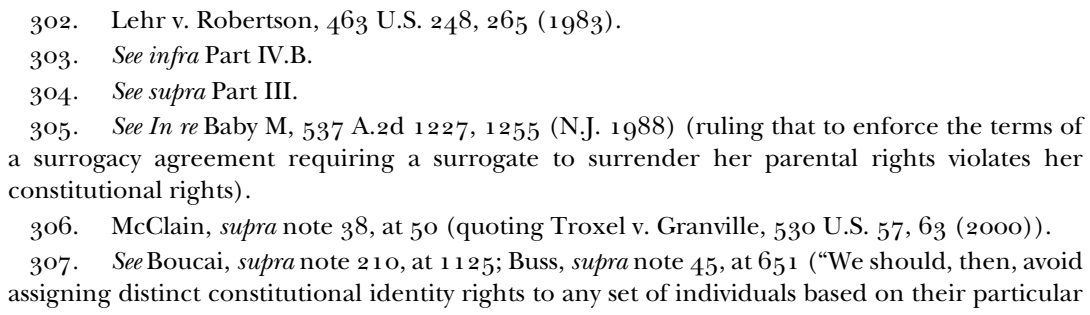


Thus, this Article proposes a "biology plus intent" standard. Under that test, an individual qualifies as a constitutional parent if that person has both a biological connection to the child and, prior to the child's birth, intended to parent the child. For a parental claimant who does not have a biological connection to the child, however, he or she can still qualify as a legal parent if (1) he or she was an intended parent to the child, and (2) there are not already two individuals who do satisfy both the biology and intent standard. To illustrate, imagine that two men, married to one another, employ a gestational surrogate to carry a child that was conceived using sperm from one of the men and an egg from an anonymous donor. The father who donated the sperm would, of course, qualify as a parent given that he is both the biological and the intended parent. It is important to note that the fact that he meets this standard should not mean the child has only one legal parent. Indeed, such a conclusion would not only ignore the reality of this child's intended family, but also the strong public policy behind recognizing two legal parents. ${ }^{308}$ Accordingly, we would look to see if there is an additional parent, and when doing so, see there is no other claimant who can claim both biology and intent. As a result, under this proposal, the inquiry would then shift to whether there is an additional claimant who at least satisfies the intent requirement, and indeed there is. Specifically, the husband's status as an intentional parent would be sufficient to qualify him as the child's other legal parent.

Although this proposal does not permit biology alone to serve as a path to constitutional parenthood, there are some exceptions where biology would be sufficient by itself. Specifically, intentional parentage would encompass those who-beyond the act of merely donating sperm or egg-played a significant role in either the conception or birth of the child. For instance, in contrast to a sperm donor, a man who fathered a child through sexual intercourse with the child's mother could still claim the status of constitutional parent even if evidence existed that he never intended to be a parent. ${ }^{\circ 09}$ Likewise, a traditional surrogate would demonstrate the requisite

characteristics."); Elizabeth Traylor, Protecting the Rights of Children of Same-Sex Parents in Indiana by Adopting a Version of the Uniform Parentage Act, 48 IND. L. REV. 695, 708 (2015) ("The definition of 'parent' has changed dramatically over the past several decades and the law needs to be flexible in order to accommodate these new family structures.").

308. See William M. Lopez, Artificial Insemination and the Presumption of Parenthood: Traditional Foundations and Modern Applications for Lesbian Mothers, 86 CHI.-KENT L. REV. 897, 902 (2011) ("[T] he best interest of the child is protected when that child has two parents."); Schiff, supra note 175 , at 285 (noting "the public policy goal of ensuring a stable family unit for the child with two nurturing and committed parents who legally are responsible for the child's well-being"); see also Ellen C. Perrin et al., Gay and Lesbian Issues in Pediatric Health Care, 34 Current Probs. PEDiatric \& AdOLESCENT HEALTH CARE 355, 378-79 (2004) ("[T] he presence of two parents, irrespective of their gender or sexual orientation, [is] associated with more positive outcomes for [a child's] psychological well-being.").

309. Thus, nothing in this proposal would alter state courts' current approach of holding men financially responsible for their biological children even if those men claim the mother 
intent, by virtue of the fact that she not only donated her eggs but also gestated the child for nine months, thus preserving her maternal rights until such time as a legal adoption can take place. Finally, as used in this proposal, an intentional parent refers to one who formed that intent prior to the child's birth and with the assent of the child's other legal parent. For those who come into a child's life after the child's birth or those whose intent was at odds with that of the child's other legal parent, such claims should instead be adjudicated pursuant to the standards regarding psychological parentage, discussed below. $3^{10}$

Despite these caveats, the intent standard might nonetheless appear to suggest quite a departure from the existing parameters of constitutional parenthood. In actuality, however, this proposal is not so much of a departure, but a more thoughtful encapsulation of the Supreme Court's existing jurisprudence on parentage. The Court's recent decision in Obergefell $v$. Hodges, which defined the fundamental right to marry to encompass same-sex marriage, is instructive. ${ }^{311}$ Both marriage and parenthood are unenumerated rights, yet both have been recognized as fundamental liberty interests, subject to protection under the Fourteenth Amendment. When the Court was called upon to define marriage, it noted that, despite the fact that same-sex marriage was absent from this country's history and traditions, the essence of that right nonetheless demanded that it be extended to same-sex couples.312 Specifically, the Court ruled that those justifications underlying the fundamental right to marry "apply with equal force to same-sex couples." ${ }^{13}$ Similarly, an examination of how the Court has defined "parent" for purposes of the corresponding fundamental right reveals three facets of constitutional

misled them as to her ability to have a child. See Jill E. Evans, In Search of Paternal Equity: A Father's Right to Pursue a Claim of Misrepresentation of Fertility, 36 LOY. U. CHI. L.J. 1045,1075 \& n.1 47 (2005) (listing cases that represent the "universal rejection of affirmative defenses or counterclaims alleging fraud in paternity or support actions"); Michelle Oberman, Sex, Lies, and the Duty to Disclose, 47 ARIz. L. REv. 871, 891-92 (2005) (summarizing courts' approaches to cases where one partner did not disclose or misrepresented his or her fertility status). Of course, it bears mentioning that the purpose of this Article is to address the question of who may avail themselves to the protections of constitutional parenthood, not who the state can treat as a parent for purposes of holding them liable for child support. This is a key distinction given that the law does not currently treat those two categories of parents equally. See Hendricks, supra note ${ }_{15}$, at 465 ("Some separation already exists under Fourteenth Amendment doctrine, which, to date, requires parents to 'earn' their parental rights (by gestation and birth, marriage, or biology-plusrelationship) but does not seem to limit the state's ability to impose parenthood on a much lesser showing (often biology or relationship).”).

310. See infra Part IV.C.

311. Obergefell v. Hodges, 135 S. Ct. 2584, 2600 (2015).

312. As the Court made clear in Lawrence $v$. Texas, "history and tradition are the starting point but not in all cases the ending point of the substantive due process inquiry." Lawrence v. Texas, 539 U.S. 558, 572 (2003) (quoting Cty. of Sacramento v. Lewis, 523 U.S. 833, 857 (1998) (Kennedy, J., concurring)).

313. Obergefell, 135 S. Ct. at 2599. 
parenthood that likewise mandate the inclusion of intentional parentage in that definition.

\section{The Limited Role of Biology}

The Court has already made clear that biology is by no means the touchstone of parenthood. In Lehr, for instance, the Supreme Court announced that, when it comes to legal parentage, "the mere existence of a biological link does not merit equivalent constitutional protection." ${ }^{14}$ Additionally, as Justice Stevens remarked in Caban, "[p]arental rights do not spring full-blown from the biological connection between parent and child. They require relationships more enduring." ${ }_{15}^{15}$ The Court's decisions in those cases shed even more light on the limited role biology plays in the resolution of parental identity claims. In Quilloin, for example, the Court was confronted with a Georgia adoption statute that required the consent of a nonmarital mother, but not a nonmarital father. ${ }^{316}$ The Court upheld the statute, finding that it "did not deprive appellant of his asserted rights under the Due Process and Equal Protection Clauses."317 Thus, the Court did not hold that Quilloin's constitutional rights were outweighed by the state's interest, but instead that he had no constitutional rights in the first place. ${ }^{318}$ Indeed, one commentator has characterized Quilloin as "reflect[ing] not a curtailment of parental rights, but rather a minimization of the role of biology in assigning those rights." 319 Not only has the court discounted the role of biology, but in Michael H., it held that the state of California could constitutionally recognize as the legal father a man, who had no biological connection with the child, simply by virtue of the fact that he was married to the mother. ${ }^{320}$ Thus, to now propose a rule in which biology alone is not dispositive of parenthood is entirely consistent with what the Court has previously indicated about the constitutional dimensions of parenthood.

\section{The Historical Link Between Parental Identity and Intact Families}

Further support for the proposition that constitutional parenthood must include considerations of intent can be found in the nation's history of linking

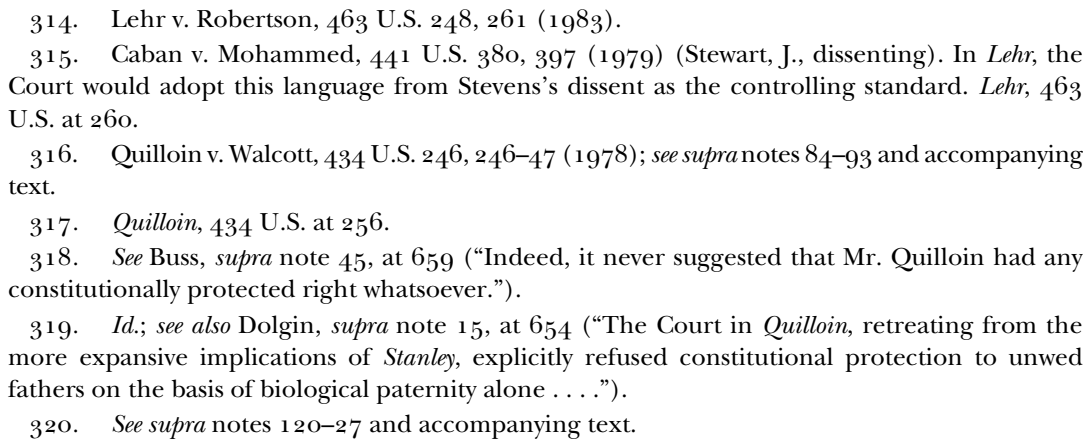


marriage and parental identity. As Douglas NeJaime has explained, "[f]amily law increasingly deemed married individuals to be legal parents based not on presumed biological connections to their children, but rather on the deliberate parent-child relationships formed inside the marital family." ${ }^{21}$ Indeed, one of the unifying threads in the fathers' rights cases was the Court's desire to give effect to intact families. ${ }^{322}$ In fact, it is this theme that has led many, when synthesizing the various holdings in the fathers' rights cases, to suggest that the nonmarital father's relationship with the mother must be taken into account. $3^{23}$

The plurality in Michael $H$. provides perhaps the best example of this approach when it held that "our traditions have protected the marital family" from claims of an "outsider" even if that person happens to be the child's biological father. ${ }^{24}$ In the absence of marriage, the Court has still indicated a preference for awarding the title of "parent" to those who took part in a marriage-like relationship with the child's other parent. In Caban, for example, the Court ruled that it was a violation of equal protection to permit nonmarital mothers, but not nonmarital fathers, to withhold consent to the adoption of their children. ${ }^{25}$ It is true, of course, that the nonmarital father prevailed largely because he had, unlike the nonmarital fathers in Quilloin and Lehr, played an active role in his children's lives. ${ }^{326}$ However, as Janet Dolgin has persuasively argued, the decision in Caban also seems to be heavily influenced by the fact that the nonmarital father had lived with both the mother and the children "as a natural family" ${ }_{327}$

Technically, the term "natural family" was used in Caban to refer to a social unit of unmarried biological parents and their children. However, the term carried additional implications. The term "family" refers, of course, to a comparable unit involving two married adults. "Natural family" is the marked term. The normal,

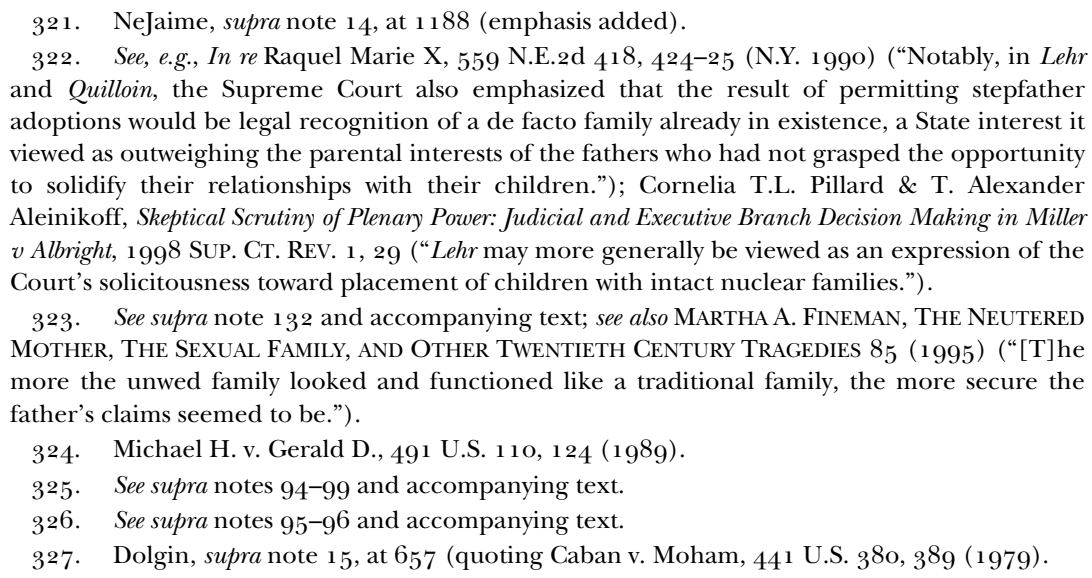


ideal family can be described without use of the adjective "natural." That adjective is used to delineate a special, marginal family group. In this regard, therefore, Caban differed from the traditional position that to achieve legal recognition, a family must include two adults married to each other. But the decision did not eliminate altogether the presence of "family" as a basic precondition for the protection of a biological father's legal paternity. ${ }^{328}$

Thus, although Caban recognized that formal marriage was no longer a requirement to create a family, parental identity did nonetheless flow, at least in part, from a relationship that bore some resemblance to marriage. ${ }^{29}$

Given, then, the goal of protecting established family units, intentional parenthood is a required component of any modern definition of constitutional parenthood. Failure to do so would allow an outsider to interfere with an existing family unit simply by virtue of a biological connection to a child in that family-a scenario the Court has explicitly rejected. For example, when the Court dismissed the biological father's attempts in Quilloin to veto a step-parent adoption, it did so in part because "the result of the adoption in this case is to give full recognition to a family unit already in existence." $33^{\circ}$ With that in mind, consider an infertile couple that uses the services of a sperm donor, an egg donor and a gestational surrogate to successfully conceive a child. Of these five people, only the intentional parents, the infertile couple, are likely to represent an existing family unit. Thus, an approach that considers both biological and intentional parenthood would permit the commissioning couple to qualify not only as the intentional parents, but also as the legal parents. In contrast, the other three contributors have no connection to the child other than gestation or gamete donation. Thus, any other decision would disperse the child's legal parentage over individuals from unrelated families, an approach the Court has repeatedly declined to adopt when dealing with cases involving parental identity. ${ }^{3{ }^{1}}$ As one scholar has noted, the "societal interest [in protecting children] is necessarily impaired if the child's legal parentage is split-possibly following protracted litigation-between two individuals who never intended to form a family." 332

\footnotetext{
328. Id. at $65^{8}$ (emphasis omitted) (footnote omitted).

329. See Hendricks, supra note 15 , at 445 ("Conservatives and feminists alike have proposed an alternative reading of the unwed father cases: that these cases are about protecting the traditional/nuclear/patriarchal family, not promoting sex equality . ...").

330. Quilloin v. Walcott, 434 U.S. 246, 255 (1978) (emphasis added).

331. See supra Part II.

332. Schiff, supra note 175 , at 285 .
} 


\section{The Importance of Safeguarding Familial Equality}

The Court has often expressed a desire to treat families and parents equally. To ensure equal protection of nontraditional families, this new test for parentage is necessary. A recurring theme in the fathers' rights cases is that a state cannot unduly discriminate when it comes to defining parenthood.333 This conclusion, of course, is hardly revolutionary in light of the protections already afforded by the Equal Protection clause. Nonetheless, looking to the fathers' rights cases, an additional dimension of antidiscrimination seems to be at play. Specifically, the fundamental right of parents is just one of several rights bundled together in the Court's broader recognition of familial privacy, a category that likewise includes abortion, contraception, and, essentially, the decision whether to have children. 334 The fathers' rights cases, in fact, evidence this commitment to safeguarding the right to reproductive freedom. Consider for instance, Stanley, where the Court struck down state attempts to automatically classify nonmarital fathers as unfit parents. 335 In ruling as it did, the Court took pains to point out its reverence for both the family itself and more specifically an individual's right to start a family: "The Court has frequently emphasized the importance of the family. The rights to conceive and to raise one's children have been deemed 'essential,' 'basic civil rights of man,' and '[r]ights far more precious . . than property rights." " ${ }_{3{ }^{6}}$ Such language harkens back to language used by the Court in Meyer $v$. Nebraska, the first case to recognize the fundamental right of parents. 337 There, when discussing the definition of "liberty" as that term is used in the Fourteenth Amendment, the Court noted that, "[w]ithout doubt, it denotes not merely freedom from bodily restraint but also the right of the

333. See, e.g., Caban v. Mohammed, 441 U.S. 380, 394 (1979) ("[T]his . . . distinction between unwed mothers and unwed fathers, applicable in all circumstances where adoption of a child of theirs is at issue, does not bear a substantial relationship to the State's asserted interests.”); Stanley v. Illinois, 405 U.S. $645,65^{8}$ (1972) (“[D] enying such a hearing to Stanley and those like him while granting it to other Illinois parents is inescapably contrary to the Equal Protection Clause.”).

334. See Meyer, supra note 55, at 528 ("Rights to abortion, contraception, marriage, kinship, and the custody and rearing of children have, for the most part, sprung up independently of one another, only later converging into a loosely recognized constellation of 'family privacy' rights."); Nancy B. Shernow, Comment, Recognizing Constitutional Rights of Custodial Parents: The Primacy of the Post-Divorce Family in Child Custody Modification Proceedings, 35 UCLA L. REV. 677, 701-02 (1988) ("The Supreme Court has recognized a fundamental right of family privacy that protects 'marriage, procreation, contraception, abortion, family relationships, and the rearing and education of children' from state interference." (footnote omitted) (quoting Developments in the Law: The Constitution and the Family, 93 HARV. L. REV. 1156,1161 (1980))).

335. See supra notes $74-84$ and accompanying text.

336. Stanley, 405 U.S. at $65^{1}$ (citations omitted).

337. Meyer v. Nebraska, 262 U.S. 39o, 399, 401 (1923); see Meyer, supra note 55, at 533 (describing Meyer and Pierce v. Society of the Sisters, 268 U.S. $5^{10}(1925)$ as being "now regarded as the foundational family privacy cases”). 
individual to [among other things,] establish a home and bring up children." $33^{8}$

Thus, for constitutional parenthood to fully protect the right of contemporary Americans to not only have children, but also to qualify as those children's legal parents, intentional parenthood must be taken into account. After all, for a variety of reasons, many families simply would not exist but for the reproductive assistance of third parties.339 The most obvious example would be an infertile couple who-unless they wish to "engag[e] in the timeconsuming, costly, and invasive process of adopti[on]" $34^{\circ}$ - must resort to assisted reproduction to have children. If there were no room for intent to factor into the determination of constitutional parenthood, those couples would never be afforded the constitutional protections of parenthoodprotections enjoyed as a matter of course by those couples who are capable of biologically reproducing on their own. As Douglas NeJaime has persuasively argued, "equality requires treating those traditionally excluded from the parentage regime as full participants." $34^{1}$

Indeed, Obergefell itself represents a particularly timely example of the Court's commitment to family equality. ${ }^{2}{ }^{2}$ When ruling that states cannot constitutionally define marriage in such a way as to exclude same-sex couples, Justice Kennedy justified that decision on a number of grounds, but one of which was the fact that "hundreds of thousands of children are presently being raised by [same-sex] couples." 343 In light of that fact, the Court ruled that same-sex marriage should be afforded constitutional protection given that " $[\mathrm{m}]$ arriage also affords the permanency and stability important to children's best interests." 344 This language would echo what the Court said two years earlier in United States v. Windsor.345 There, when talking about the impact of DOMA on same-sex families, the Court referenced the children of

338. Meyer, 262 U.S. at 399.

339. See supra Part III.A-B. Douglas NeJaime describes the situation many found themselves in prior to the development of ART:

For centuries, individuals who aspired to parenthood as a meaningful life project had their desires frustrated. Women who could not become pregnant or carry a pregnancy to term, as well as men who suffered from infertility, would live without the families they imagined. Adoption became widespread over the course of the twentieth century and offered a path to parenthood for some, but many either had their attempts rejected by restrictive adoption regimes or simply decided to forego parenting without the possibility of biological children .... In the late twentieth century, assisted reproductive technologies (ART) offered new hope to these individuals ....

NeJaime, supra note 45 , at 2285 .

340. NeJaime, supra note 45 , at 2264 .

341. Id. at 2332 .

342. Obergefell v. Hodges, 135 S. Ct. 2584, 2588-91 (2015).

343. Id. at 2600 .

344. Id.

345. United States v. Windsor, 133 S. Ct. 2675 (2013). 
those families: "[I] t humiliates tens of thousands of children now being raised by same-sex couples. The law in question makes it even more difficult for the children to understand the integrity and closeness of their own family." $34^{6}$

The recognition and dignity that both Windsor and Obergefell attempted to provide same-sex families, however, now risks being taken away as states adopt restrictive definitions of "parenthood"-definitions that require samesex couples to meet additional, more onerous requirements simply to qualify as legal parents to the children who comprise their family. 347 Thus, to protect these families from such invidious discrimination, the Court must incorporate an intent standard into the test for constitutional parenthood. Doing so would allow same-sex couples, along with individuals who utilize assisted reproduction, to make the decision to start a family, safe in the knowledge that they will be afforded the same constitutional protections as other families. $34^{8}$

In sum, although the Court has thus far only dealt with parental identity cases concerning biological parenthood, what the Court has said about the subject of parental identity makes clear that intentional parenthood is required in order to achieve the underlying objectives of constitutional parenthood.

\section{B. FUNCTIONAL PARENTHOOD}

In proposing that the constitutional definition of parent encompass both biology and intent, this Article does not mean to suggest that an individual may attain constitutional parenthood merely by satisfying those two criteria. As David Meyer has described, "[v]irtually all conceptions of parenthood rights proceed on the assumption that they are only prima facie or presumptive."349 That is precisely the approach the Supreme Court has taken

346. Id. at 2694 .

347. Typically that requirement will be formal adoption, a step that opposite-sex partners need not follow to qualify as a parent. See supra Part III.B.

348. In fact, the Court recently affirmed its position in Obergefell that, when it comes to married couples, the Constitution does not permit the states to discriminate on the basis of family composition. In Pavan v. Smith, the Court issued a summary reversal of an opinion by the Supreme Court of Arkansas applying the marital presumption to heterosexual couples but not homosexual couples. Pavan v. Smith, 137 S. Ct. 2075, 2077-79 (2017); see supra note 132 and accompanying text. Specifically, when it came to children who were the product of artificial insemination, the state issued birth certificates to married, opposite-sex couples bearing the names of both spouses, even if the husband was not the biological father. Pavan, 137 S. Ct. at 2077 . For married couples that were of the same sex, however, the state would only issue birth certificates bearing the name of the biological parent. $I d$. In ruling as it did, the Court did not address constitutional parenthood, but the Court did hold that the state must afford all married couples, whether same-sex or opposite-sex, the same benefits of marriage: "The State uses those certificates to give married parents a form of legal recognition that is not available to unmarried parents. Having made that choice, Arkansas may not, consistent with Obergefell, deny married same-sex couples that recognition." Id. at 2078-79.

349. Meyer, supra note 132, at 136. 
in the past when it held that, although a nonmarital father gains an "opportunity" to develop a parental relationship with his child by virtue of a biological connection, that opportunity does not ripen into a constitutionally protected liberty interest unless the man affirmatively "comes forward to participate in the rearing of his child." $35^{\circ}$ Under this Article's proposed definition, functional parenthood would continue to play a crucial role in the determination of whether an individual has perfected the full constitutional rights of a parent. An individual who has both a biological connection to the child and was the child's intended parent would have an opportunity analogous to what the Court identified in Lehr. However, that person would still need to come forward and effectively parent the child in order to qualify as a parent subject to full constitutional protection.

It is important to note, however, that in the past the Supreme Court has implied that men and women, given their differing levels of involvement in human reproduction, may be treated differently when it comes to functional parenthood:

Biology, in short, gives men options. An unwed biological father may establish a relationship with his biological child and with that child's mother through appropriate behavior and become a legal father. Alternatively, he may treat the biological relationship as irrelevant and not become a father at all. ... Mothers, wed or unwed, do not have the same choices. The Supreme Court implied that for mothers, parental rights do spring from a biological, though not from a genetic, connection between parent and child. Biology gives men the chance to become fathers. However, it inexorably makes women mothers. $35^{1}$

By retaining the functional requirement in the proposed definition of constitutional parenthood, this Article does not suggest or endorse deviating from this understanding when it comes to women who are both the biological and the gestational mother. In short, "the process of growing a fetus, laboring, and delivering a child" $35^{2}$ that biological mothers undertake is, in contrast to the role played by biological fathers, likely sufficient by itself to fulfill the functional parenthood requirement. 353

Nonetheless, in light of the refined test of constitutional parenthood for assisted reproduction, women who do not play both the biological and

350. Lehr v. Robertson, 463 U.S. 248, 267 (1983) (quoting Caban v. Mohammed, 441 U.S. $380,392(1979))$.

351. Dolgin, supra note ${ }_{15}$, at 661 (footnotes omitted).

352. Hendricks, supra note ${ }_{15}$, at 469; see also Karen Czapanskiy, Volunteers and Draftees: The Struggle for Parental Equality, 38 UCLA L. REV. 1415 , 1416 (1992) (describing biological fathers as "volunteers" and biological mothers as "draftees").

353. But see Hendricks, supra note 15 , at 470-71 (noting how, in subsequent cases, some of the justices suggested "that a new mother, ... like the unwed fathers in Stanley and Lehr, might have no parental rights until she takes additional steps to establish a post-birth relationship"). 
getational roles might now be required to demonstrate functional parenthood as a requirement to gaining full constitutional protections. Consider for instance, an intended mother and father who use a gestational surrogate to carry a child conceived using third-party sperm and egg donors. Under the proposed standard, no individual would satisfy the biology plus intent requirement. Accordingly, a court would then look solely to who intended to parent the child, which would mean that the commissioning couple would be the legal parents. Nonetheless, both would still need to function as parents prior to achieving full constitutional status. After all, unlike traditional procreation, the mother and father in this scenario would be similarly situated vis-à-vis their biological involvement in the child's birth. The same would be true if the surrogate was implanted with an egg from the intended mother that had been fertilized by sperm from the intended father.354 The commissioning couple would still qualify as the legal parents given that both would now satisfy the biology plus intent requirement, but both would still need to come forward and accept that role for it to fully ripen into the corresponding constitutional right. Again, in this scenario, the mother and father are similarly situated in that both played the same biological role in the birth of the child - they both donated the required gametes-and nothing more. 355

Most individuals who satisfy the biology plus intent standard would, one would assume, eagerly avail themselves of the opportunity to foster the requisite parent-child relationship with their offspring. Thus, the functional parenthood requirement should not be considered a hurdle that caring parents must jump through in order to secure the protections of constitutional parenthood. Instead, the requirement protects children from presumptive parents holding them hostage while refusing to parent the child and refusing to allow anyone else to legally assume that role. That precise situation was what confronted the Court in both Quilloin and Lehr, where a nonmarital, biological father, despite not participating in his child's life, refused to consent to the child's adoption by another man. $35^{6}$ In both cases, the Court deemed the fathers' consent irrelevant given that neither had fulfilled the role of functional parent.357 In short, the Court's approach to parental identity, which is retained in the proposal here, has been one that

354. This was precisely the fact pattern presented in Johnson $v$. Calvert. Johnson v. Calvert, $85^{1}$ P.2d 776, 778 (Cal. 1993).

355. See Susan Frelich Appleton, Presuming Women: Revisiting the Presumption of Legitimacy in the Same-Sex Couples Era, 86 B.U. L. REV. 227, 277 (2006) ("[R]elying on intent to determine parentage holds promise for freeing family law from gender stereotypes and assumptions about biology as destiny. An intent-based test puts males and females on equal footing, offsetting rather than reinforcing biological sex differences." (footnotes omitted)).

$35^{6}$. See supra notes $84-92,100-12$ and accompanying text.

357. See supra notes $84-92,100-12$ and accompanying text. 
provides the state with greater options to find parents for children whose current "parents" are refusing to fulfill the obligations of that role.

That being said, in requiring parents to come forward and demonstrate their commitment to the child, the above examples assume that the intended mother(s) and father(s) had the opportunity to do just that. What about parents who would have parented the child but were unaware, through no fault of their own, that they even had a biological child? The classic example would be a nonmarital father who never learned that he had a child because the mother gave birth in secret and immediately put the child up for adoption. $.5^{8}$ In light of assisted reproduction technology, however, a similar scenario could now happen involving mothers. Assume that a married couple used their genetic material to create fertilized eggs, which they stored for possible future use. The couple subsequently divorces, and the husband implants one of the eggs in a gestational surrogate without informing his former wife. 359 In that case, the biological mother had previously expressed an intent, by virtue of harvesting and storing the fertilized eggs, to be a mother. Yet because of the husband's deceit, the mother is now denied an opportunity to come forward and affirmatively demonstrate that commitment. $3^{60}$ How, then, would that incapacity impact her ability to claim constitutional parenthood? Sadly, the Supreme Court has issued no substantive guidance on this issue, merely asking whether the law "adequately protected [the parents'] opportunity to form such a relationship." ${ }^{61}$ Although it is beyond the scope of this Article to suggest how this issue should be resolved, it is clear that the societal changes discussed herein have not only exacerbated determinations of constitutional parenthood, they have likewise made more compelling the question of what steps a state must take in order to protect a parent's opportunity to become a functional parent.

358. See Michael J. Higdon, Marginalized Fathers and Demonized Mothers: A Feminist Look at the Reproductive Freedom of Unmarried Men, 66 ALA. L. REV. 507, 527-31 (2015) (giving examples of "thwarted fathers").

359. Indeed, a number of women have had their eggs implanted in others without their consent. See Stone v. Regents of Univ. of Cal., 92 Cal. Rptr. 2d 94, 96 (Ct. App. 1999) ("[H]uman eggs were taken from one patient and implanted in another without the consent of the donor.”); see also Judith D. Fischer, Misappropriation of Human Eggs and Embryos and the Tort of Conversion: A Relational View, 32 LOY. L.A. L. REV. 381, 397-402 (1999) (discussing instances of stolen eggs).

36o. See Molly Miller, Note, Embryo Adoption: The Solution to an Ambiguous Intent Standard, 94 MiNN. L. REV. 869, 882-83 (2010) ("Further, the biology-based standards do not protect embryo creators from having their embryos stolen and implanted without their consent. In contrast, an intent standard would overcome the barriers that biology imposes by being more broadly applicable." (footnote omitted)).

361. Lehr v. Robertson, 463 U.S. 248, 263 (1983). 


\section{PSyChological PARENTAGE AND State AUtonomy}

As indicated above, this Article proposes that functional parenthood continue to play a role in the constitutional definition of parent. $3^{62}$ It does not suggest, however, allowing functional parentage-absent biology and intent-to independently qualify as a basis for constitutional parenthood. This limitation does not mean to suggest that states cannot continue to recognize psychological parentage for purposes of awarding parental rights, $3^{63}$ but only that this variety of parentage would not by itself entitle one to the constitutional protections associated with legal parenthood.

Such an approach is essential in order to safeguard the states' interest in protecting families. After all, an overly prescriptive definition of constitutional parenthood can, in the words of Professor Elizabeth Patterson, lead to "changes in state law that could disrupt the fabric of family law and policy in a state. Because family policy is so closely connected to community norms and local social cohesion, such disruptions can have deleterious social effects ...." $3_{4}{ }_{4}$ For instance, the recognition of psychological parenthood would mean that, given there is no limit to the number of individuals who could claim that status, more than two people could now share parental rights to a single child. ${ }^{65}$ Although some have indeed proposed lifting the current quantitative limitation, ${ }^{66}$ it is the position of this Article that such decisions should be left to the individual states and, for a variety of reasons, not enshrined into constitutional law.

First, unlike an intent requirement, which the Supreme Court's jurisprudence already supports as a necessary addition to the test for parental identity, ${ }^{367}$ nothing in the Court's history supports any model of family in which there are more than two legal parents. Second, psychological parentage typically arises when one who is neither a biological nor an intentional parent subsequently enters a child's life and begins acting as a parent. ${ }^{68}$ Given this factual context, the equality concerns that militated against excluding intentional parents from the definition of constitutional parenthood no

\footnotetext{
362. See supra Part IV.B.

363. See supra Part III.C.

364. Elizabeth G. Patterson, Unintended Consequences: Why Congress Should Tread Lightly When Entering the Field of Family Law, 25 GA. ST. U. L. REV. 397, 399 (2008).

365 . See Buss, supra note 45 , at $640-41$ (describing the approach of the ALI Principles as "encourag[ing] courts to draw additional claimants into the custodial circle ... [in such a way that] the court can proliferate custodial fragments among individuals to whom the law assigns, at best, qualified parental identity and responsibility").

366. Laura T. Kessler, Community Parenting, 24 WASH. U. J.L. \& POL'Y 47, 50 (2007) (advocating that "the numerosity requirement that a child shall have no more than two parents" be lifted).

367. See supra Part IV.A.

368. See supra Part III.C.
} 
longer exist. $3^{69}$ After all, intentional parenthood protects the subset of families who must resort to some version of assisted reproduction to even have children. Given that psychological parentage, however, would arise only after the child has already been born, those concerns are not present. Further, a psychological parent who desires a legal relationship with a parentless child can turn to adoption-an option that most "parents" in that situation would likely assume was required in order to become a legal parent. ${ }^{\circ} 7^{\circ}$ In contrast, as Douglas NeJaime has pointed out, those parents who intended to parent a child before that child was even born are more likely to be "ignorant of the need to adopt their own child." ${ }_{71}$ Thus, intentional parents, unlike psychological parents, are typically going to be more in need of the protections that constitutional parenthood affords. ${ }^{37^{2}}$ Finally, any decision to expand the number of individuals who can claim parental rights could result in harm to the child, who is now subject to the control of multiple individuals. As one scholar aptly points out, "[t] he best interests of the child are not served by granting rights to more and more parental claimants or by creating new varieties of constitutionally protected parenthood." 373

Thus, decisions about whether to recognize psychological parentage should be left to state law with the understanding that any such recognition is independent of constitutional parenthood. In fact, such an approach is consistent with what the states themselves are already doing. Specifically, the states that have thus far offered this recognition have done so not on the basis of protecting "the proprietary interests of the parent as a rights-holder," 374 but instead as a means of protecting the best interest of children who have come to rely on these extra-parental relationships. ${ }^{375}$ Indeed, when recognizing psychological parentage, courts have used that status merely as a means of awarding parental rights, not bestowing legal parenthood. ${ }^{36}$ As the Supreme Court has previously recognized, areas such as this are best handled by the state courts given that they "are more eminently suited to work of this type

369. See supra notes $330-46$ and accompanying text.

370. See supra notes $254^{-61}$ and accompanying text. One of the reasons the court in that case refused to recognize the petitioner as an "equitable parent" was because he was aware "at all times that he would have to formally adopt William in order to be his legal parent." In re Marriage of Mancine, 9 N.E. 3 d 55 , 566, 568 (Ill. App. Ct. 2014).

371 . NeJaime, supra note 45 , at 2320 (emphasis added).

372. Ohio v. Akron Ctr. for Reprod. Health, 497 U.S. 502, $54^{1}$ (1990) (Blackmun, J., dissenting) ("Some of this may be so 'in most cases' and, it is to be hoped, in judges' own and other warm and protected, nurturing family environments. But those 'most cases' need not rely on constitutional protections that are so vital for others."); Suzanna Sherry, Original Sin, 84 Nw. U. L. REV. 1215 , 1219 (1990) (noting the importance of "extending substantive constitutional protections to those most in need of the judiciary's assistance").

373. SHULman, supra note 44 , at 205.

374. Id. at 14 .

375. See supra notes 271, 273 and accompanying text.

376 . See supra note 274 and accompanying text. 
than are federal courts, which lack the close association with state and local government organizations dedicated to handling issues that arise out of conflicts over divorce, alimony, and child custody decrees." 377 The same cannot be said, however, when it comes to advocating for a more robust constitutional definition of parenthood. As Professor Jeffrey Parness has argued, "the more particular articulation of who are federal constitutional childcare rightholders, without determining which parent has custody, visitation, parenting time, or the like, should prompt no concerns over later monitoring, implicate no ties to local government organizations, nor require judicial expertise developed only in state courts." ${ }_{37}$

Admittedly, the extent to which the states can navigate in this area remains somewhat unclear.379 After all, any parental rights afforded a third party would necessarily impact the fundamental rights of the legal parents "to make decisions concerning their children." $3^{80}$ Although a full analysis of this issue is beyond the discrete focus of this Article, the Supreme Court has indicated that the states do have some ability to award third-party visitation, albeit the boundaries of that ability are still far from certain..$^{81}$ The point here is merely that, to the extent parental rights can constitutionally be extended to third parties, that decision should not emanate from the definition of constitutional parenthood, but should instead be retained by the states. As one scholar succinctly put it, "[b] asic rights inevitably require some diversity in parenthood but do not compel public acquiescence in whatever child care arrangements adults may agree upon." $3^{82}$

377. Ankenbrandt v. Richards, 504 U.S. 689, 704 (1992); see also Buss, supra note 45, at $65^{2-53}$ (noting ways in which the state is "uniquely qualified" and has "superior competence" in resolving such issues).

378. Parness, supra note 45 , at 983 .

379. Although the Court has weighed in on the constitutionality of third-party visitation statutes in Troxel v. Granville, 530 U.S. 57 (2000), "[t] he Court's six opinions [in that case] left a great deal of uncertainty for states that want to allow non-parental visitation orders." Hendricks, supra note 15 , at 455 .

380. Solangel Maldonado, When Father (or Mother) Doesn't Know Best: Quasi-Parents and Parental Deference After Troxel v. Granville, 88 IOWA L. REV. 865, 877 (2003).

381. See Meyer, supra note 20, at 867 (noting that Troxel "limits state power to redefine the substantive prerogatives accorded parents, but does not "place any constitutional limitations on the ability of states to legislatively, or through their common law, define a parent or family" (quoting In re Parentage of L.B., 122 P.3d 161, 178 (Wash. 2005))); Meyer, supra note 132, at 133 (noting how, with Troxel, "the Supreme Court has signaled a growing receptiveness to extending constitutional protection to the independent relational interests of children"); Adam Winkler, Fatal in Theory and Strict in Fact: An Empirical Analysis of Strict Scrutiny in the Federal Courts, 59 VAND. L. REV. 793, 864 n.324 (2006) ("Troxel has led to an avalanche of state court litigation over the constitutionality of child custody and visitation laws.”).

382. Meyer, supra note 132 , at 125 . 


\section{CONCLUSION}

The Supreme Court recently noted that " $[\mathrm{t}]$ he states are laboratories for experimentation, but those experiments may not deny the basic dignity the Constitution protects." 383 Unfortunately, that is precisely the current state of the law as it applies to parental identity. Given the Supreme Court's sustained silence on the subject, the states have individually undertaken the difficult task of defining parenthood, a status that brings with it significant constitutional protections. As a consequence, two distinct harms have emerged. First, a person's ability to avail herself to the constitutional protections associated with parenthood now varies depending on the state in which she happens to live. Second, some states have defined parenthood in such a restrictive manner that certain kinds of families are effectively precluded from ever enjoying those protections. As discussed herein, the solution to both problems begins with the Supreme Court. The Court itself acknowledged this responsibility when it said, "we cannot leave to the States the formulation of the authoritative laws, rules, and remedies designed to protect people from infractions by the States of federally guaranteed rights." ${ }^{8}{ }_{4}$ Instead, when it comes to such rights, "it is our responsibility to protect by fashioning the necessary rule." 385 Thus, it is time for the Court to return to the subject of constitutional parenthood and provide a more contemporary definition-one that, at a minimum, both recognizes and protects the rights of intentional parents. Only by doing so will the Court adequately safeguard the constitutional rights of the ever-evolving American family.

383. Hall v. Florida, 134 S. Ct. 1986, 2001 (2014).

384. Chapman v. California, 386 U.S. 18 , 21 (1967).

385 . Id. 